\title{
Current and Future Molecular Testing in NSCLC, What Can We Expect from New Sequencing Technologies?
}

\author{
Simon Garinet ${ }^{1,2}$, Pierre Laurent-Puig ${ }^{1,2}{ }^{\mathbb{C}}$, Hélène Blons ${ }^{1,2, *}$ and Jean-Baptiste Oudart ${ }^{2}$ \\ 1 INSERM UMR-S1147, Paris Sorbonne Cite University, 75270 Paris Cedex 06, France; \\ simon.garinet@aphp.fr (S.G.); pierre.laurent-puig@parisdescartes.fr (P.L.-P.) \\ 2 Department of Biochemistry, Unit of Pharmacogenetics and Molecular Oncology, Georges Pompidou \\ European Hospital, Assistance Publique-Hôpitaux de Paris, 75015 Paris, France; joudart@chu-reims.fr \\ * Correspondence: helene.blons@aphp.fr; Tel.: +33-1-4286-4067
}

Received: 24 May 2018; Accepted: 6 June 2018; Published: 9 June 2018

\begin{abstract}
Recent changes in lung cancer care, including new approvals in first line and the introduction of high-throughput molecular technologies in routine testing led us to question ourselves on how deeper molecular testing may be helpful for the optimal use of targeted drugs. In this article, we review recent results in the scope of personalized medicine in lung cancer. We discuss biomarkers that have a therapeutic predictive value in lung cancer with a focus on recent changes and on the clinical value of large scale sequencing strategies. We review the use of second- and third-generation EGFR and ALK inhibitors with a focus on secondary resistance alterations. We discuss anti-BRAF and anti-MEK combo, emerging biomarkers as NRG1 and NTRKs fusions and immunotherapy. Finally, we discuss the different technical issues of comprehensive molecular profiling and show how large screenings might refine the prediction value of individual markers. Based on a review of recent publications (2012-2018), we address promising approaches for the treatment of patients with lung cancers and the technical challenges associated with the identification of new predictive markers.
\end{abstract}

Keywords: lung cancer; molecular analysis; NGS; oncogene drivers

\section{Introduction}

Lung cancer remains the most common cause of cancer deaths worldwide with more than a million deaths per year [1]. It is divided into non-small cell lung cancer (NSCLC), which accounts for $80-85 \%$ of cases, and small cell lung cancer (SCLC). Although tobacco is the major risk factor for lung cancer, $10-15 \%$ of patients in Caucasians and up to $40 \%$ in Asians are non-smokers. Risk factors and disease etiology remain largely unknown in non-smokers even though hypotheses in Asian populations have been made concerning the role of second hand smoke, cooking fumes, or specific environmental factors. However, interrogation of molecular signatures in Asians led to the conclusion that the elevated rate of NSCLC in Asian non-smokers was not related to second hand smoke [2]. In non-smokers, carcinogenesis is often linked to the presence of somatic molecular alterations in specific oncogenic drivers. The use of selective inhibitors such as anti-EGFR or anti-ALK therapies in patients can lead to tumor shrinkage and prolonged survival. It was rapidly demonstrated that the selection of patients that benefit from targeted treatments could not be based on clinical data. This statement led to the generalization of mutation screening in care settings to identify oncogenic drivers. All patients with stage IV or inoperable lung cancer and all non-smokers with lung cancer independently of cancer type should have tumor molecular testing. Because targetable oncogenic drivers are more common in non-smokers, high-throughput strategies should be proposed in this situation when no frequent alteration is found by basic tests.

Before molecular testing, the first step remains pathological diagnosis and immunohistochemistry (IHC) analysis of protein biomarkers such as thyroid transcription factor-1 (TTF-1), programmed 
death-ligand 1 (PD-L1), anaplastic lymphoma kinase (ALK) or ROS1. Due to the importance of molecular testing for lung cancer patients, the pathologist must remember to save material for subsequent analysis. If liquid biopsies are validated biomarkers to identify oncogene drivers, molecular tumor testing remains the gold standard at least at diagnosis. Indeed, circulating tumor DNA is contributory in $70 \%$ of patients with stage IV tumors.

Comprehensive molecular profiling has revealed major heterogeneity and many different oncogenic drivers have been identified in lung cancer. The implementation of large molecular testing for every patient would ideally inform on all type of alterations, both frequent and rare events. However high-throughput assays are not valuable to all patients in care settings. Whole exome sequencing (WES), RNA sequencing, or large comprehensive tests are not always the appropriate strategy because of tissue type, cellularity, turnaround time, and costs. However, validated druggable alterations need to be accurately identified for all patients, then potential targets might be assessed and finally molecular tumor boards may validate and organize high-throughput tests for patients that need extended screening.

Numerous targeted therapies have been developed in recent years, particularly in lung cancer [3-6]. Such therapies changed the standard of care for NSCLC stages III and IV from cytotoxic chemotherapies to "specific" first line treatment for selected patients [7]. Initially used in unselected patient populations, most targeted drugs failed [3]. This stressed the need for classifications of tumor subtypes and identification of predictive biomarkers. Initially used in research, next generation sequencing (NGS) revolutionized the approach from single gene sequencing to high-throughput characterization. NGS offers a wide range of possibilities from targeted panels testing a few dozen genes to whole exome or genome sequencing [8]. In addition to its outstanding high-throughput sequencing capacity, NGS has major advantages over first generation sequencing. The quantification of mutation ratio is possible and allows the identification of clonal events in the tumor [9]. Detection cutoffs depend on the coverage depth. For targeted gene panels, the average sensitivity is $2 \%$, enabling the detection of low frequency mutations even when low-inputs of tumor DNA are available. For large targeted panels (more than 300 genes) or exomes, sensitivity is around $10 \%$ and it is not recommended to use low quality samples or samples with less than $50 \%$ tumor cell content. In research programs, comprehensive pangenomic studies integrate not only mutation testing but transcriptomics data or miRs expression data using RNAseq and miRNA-seq and epigenetics features such as DNA methylation with Methyl-seq, or histone signatures with Chip-seq. These pangenomic studies led by collaborative projects—-such as The Cancer Genome Atlas (TCGA) and the International Cancer Genome Consortium (ICGC) — have largely characterized genetic and epigenetic abnormalities of numerous cancer types on large cohorts of patients [10-13], showing that individual cancer genomes can technically be entirely explored. However, if mutation testing remains feasible, tumor comprehensive analysis translation to routine diagnostic remains a technical and clinical challenge for hospital laboratories.

At present in lung cancer, clinical molecular diagnosis consists of identifying druggable alterations. Clinical molecular biomarkers can be divided into: gene fusions, gene amplifications, and gene mutations. Gene mutations were analyzed since the identification of EGFR mutations as predictive markers of response to EGFR tyrosine kinase inhibitors (EGFR-TKIs) and gene fusions or amplifications can be tested at the cellular level by IHC-, or at the cytogenetic level by fluorescent in situ hybridization (FISH). Because larger mutation screenings-including RAS, BRAF, MET (mutations, amplifications), ERBB2 (mutations, amplifications), ALK (mutations) and ROS (mutations)-were shown to be useful in the management of lung cancer patients, targeted NGS is progressively replacing single gene testing methods. These focused NGS strategies are easy to handle, low cost, and suitable for FFPE samples and low DNA-inputs. Detection cutoff is low (2\%) and allows the identification of mutations and amplifications [14]. More specific NGS focused panels use RNA as input and may identify pre-specified fusions such as ALK, ROS RET, NTRKs, and NRG1. 
What can we expect from these technologies that could orient decision-making? Dual testing using a DNA and RNA focus panel should allow also an almost complete detection of known druggable targets and are applicable to most samples and patients. For patients undergoing large-scale cancer molecular studies such as exome, RNAseq, and large targeted panels, genetic counseling should be organized to discuss incidental findings such as mutations in cancer susceptibility genes and informed consent should be obtained.

We will discuss molecular strategies available in routine care for NSCLC screening, we will define strength and weakness and review new biomarkers related to new treatment options, combinations, and treatment sequences.

\section{1-Lung Cancer Molecular Screenings, Update on Validated Markers and Emerging Ones}

\section{1. -Mutation Testing}

\subsubsection{EGFR}

The epidermal growth factor receptor (EGFR) was the first oncogenic target to be discovered in NSCLC. The prevalence of EGFR mutations ranges from $40 \%$ in Asiatic patients [15] to $11-17 \%$ in Caucasian patients $[16,17]$. Smokers or former smokers are associated with a lower incidence of EGFR mutation [18]. EGFR mutations are mainly associated with female gender and adenocarcinoma histology.

Almost all EGFR mutations involve exons 18 to 21. Small in-frame deletions in exon 19 (del 19) represent about $40-50 \%$ of EGFR mutations $[19,20]$ while p.Leu858Arg amino acid substitution in exon 21 accounts for 30-40\% [17,21]. Uncommon EGFR mutations, 10-18\% of EGFR mutated samples are defined as EGFR mutations that are neither exon 19 deletions nor p.Leu858Arg substitution [22,23] and include exon 20 insertions and a few exon 18 alterations for the most frequent rare alterations. A heterogeneous group of complex mutations mainly composed of an association of classical mutations and uncommon ones has also been reported $[19,20,22,24]$. All of these mutations lead to a constitutive activation of EGFR but are not equivalent in terms of EGFR-TKI predictive value [25].

First- and Second-Generation EGFR-TKIs

The management of advanced NSCLC has been clearly improved by the development of EGFR tyrosine kinase inhibitors (EGFR-TKIs) during the last decade.

First generation EGFR-TKIs, erlotinib and gefitinib, reversibly bind the ATP-binding site of the EGFR tyrosine kinase domain and inhibit autophosphorylation thereby blocking EGFR-induced activation of the downstream signaling pathways (i.e., Akt-mTOR pathway and mitogen-activated protein kinases (MAPK) pathway) [26]. Numerous clinical trials (IPASS, WJTOG3405, NEJ-002, OPTIMAL, EURTAC, first-signal) have demonstrated an increased progression free survival (PFS) in patients treated by first generation EGFR-TKI compared to platinum-based chemotherapy. These studies mainly enrolled previously untreated patients with common EGFR mutation (del 19 or p.Leu858Arg) [27].

Second generation EGFR-TKI, afatinib irreversibly binds the intracellular kinase domain of EGFR, HER2, and HER4 [28]. LUX-lung 3 phase III study showed in previously untreated patients, an improved PFS for afatinib compared to platinum-based chemotherapy (11.1 vs. 6.9 months respectively) [29]. This increased PFS was confirmed in the LUX-lung 6 study [30].

In the LUX-lung 3 and LUX-lung 6 phase III trials, the overall survival (OS) was not significantly longer in the afatinib group compared to the chemotherapy group ( $23.1 \mathrm{vs.} 23.5$ months, respectively). However, in EGFR del 19 mutated subgroup, OS was significantly higher in the afatinib group in both trials (33.3 vs. 21.1 months in LUX-lung 3 trial and 31.4 vs. 18.4 months in LUX-lung 6 trial, respectively) [31]. 
The LUX-lung 7 phase IIB clinical trial compared afatinib with gefitinib in the first-line treatment of patients and showed a significant increase in PFS in the afatinib group (median 11 vs. 10.9 months respectively, HR: $0.73, p=0.017$ ] [32]. However, there was no significant difference in OS between afatinib and gefitinib (27.9 vs. 24.5 months, respectively) [33].

All of these results suggest that EGFR-TKIs remain the best first-line therapy in EGFR-mutated advanced NSCLC. The choice of first line between first and second generation is mainly related to different toxicity profiles and to mutation type.

\section{EGFR-TKIs Treatment for Patients with Uncommon EGFR Mutated Tumors}

Whereas the use of EGFR-TKIs as first-line treatment for patients with EGFR mutated tumors is no longer discussed, the efficacy of these treatments in case of uncommon EGFR mutations is not clearly defined. Only a few studies have investigated the action of EGFR TKIs on uncommon EGFR mutations.

Different studies have evaluated the efficacy of first-generation EGFR-TKIs in the treatment of 'frequent uncommon' EGFR substitutions p.Gly719X and p.Leu861Gln. These treatments seem to be active on these mutations but remain less effective than in those with common mutations. In 2015, Chiu et al. showed an objective response rate (ORR) and disease control rate (DCR) significantly lower compared with common mutations (ORR: $41.6 \%$ vs. $66.5 \%$ and DCR: $76.6 \%$ vs. $95.1 \%$, respectively) [34]. These results are consistent with those published by Zhang et al. in 2017 [35] and Wu et al. in 2011 [36]. The NEJ002 study showed a shorter OS among patients with uncommon EGFR mutations p.Gly719X or p.Leu861Gln compared with common EGFR mutations [37]. Despite these results, the National Comprehensive Cancer Network (NCCN) guidelines include exon 18 p.Gly719X and exon 21 p.Leu861Gln as drug-sensitive mutations [38]. Concerning the exon 20 EGFR p.Ser768Ile substitution response to first generation EGFR TKIs was lower than that of common mutations [36]. This mutation is not currently classified as a drug-sensitive mutation by NCCN guideline [38].

A post hoc analysis of LUX trials using 32 samples with uncommon EGFR mutations and compound alterations (p.Leu861Gln, p.Gly719X, and/or p.Ser768lle) tested the efficacy of second generation TKI afatinib. Most patients responded to treatment and frontline use of the drug was expanded by the FDA to patients with rare alterations [19,39], suggesting that afatinib might be a good alternative in first line for patients with uncommon sensitive alterations.

First- and second-generation EGFR TKIs are ineffective treatments on patients with EGFR exon 20 insertion mutated tumors [19,31]. Platinum-based chemotherapy remains the best first-line option for these patients.

\section{Third-Generation EGFR-TKI}

Third-generation EGFR-TKI was developed to specifically overcome the EGFR exon 20 p.Thr790Met resistance mutation, which is the most common mechanism of drug resistance to first and second-generation EGFR-TKIs (Figure 1A). Osimertinib (AZD9291) is an irreversible EGFR kinase domain inhibitor targeting the cysteine-797 residue within the ATP binding site [40]. It is effective both against common EGFR mutated lung cancers (i.e., deletion in exon 19 or p.Leu858Arg) and exon 20 resistance mutations (p.Thr790Met).

However, Osimertinib remains ineffective against other mechanism of EGFR-TKIs resistance such as EGFR exon 20 insertion, MET or ERBB2 amplifications, epithelial-to-mesenchymal transition (EMT) or acquired mutations in BRAF, PIK3CA, KRAS, and NRAS genes [41].

The phase I/II AURA clinical trial [42] enrolled patients with advanced lung cancer that progressed after EGFR-TKI treatment. The median PFS was 9.6 months in patients with EGFR p.Thr790Met mutated tumors and 2.8 months in EGFR p.Thr790Met negative patients. The existence of other acquired resistance mechanisms has not been studied in these patients.

The AURA 3 clinical trial [43] compared osimertinib vs. platinum-based chemotherapy plus pemetrexed in patients with EGFR p.Thr790Met mutated tumors who had disease progression after first generation EGFR-TKI. The median PFS was significantly longer with osimertinib compared to 
chemotherapy (10.1 vs. 4.4 months, respectively) and the ORR was also increased ( $71 \%$ vs. $31 \%$ ). Osimertinib is now recommended as second line therapy for patients with EGFR p.Thr790Met mutated tumors. To confirm the efficacy of osimertinib as a second line treatment, the ASTRIS phase III clinical trial (NCT02474355) is currently in progress and includes patients with advanced or metastatic EGFR p.Thr790Met mutation-positive NSCLC that have progressed after treatment with EGFR-TKIs therapy.

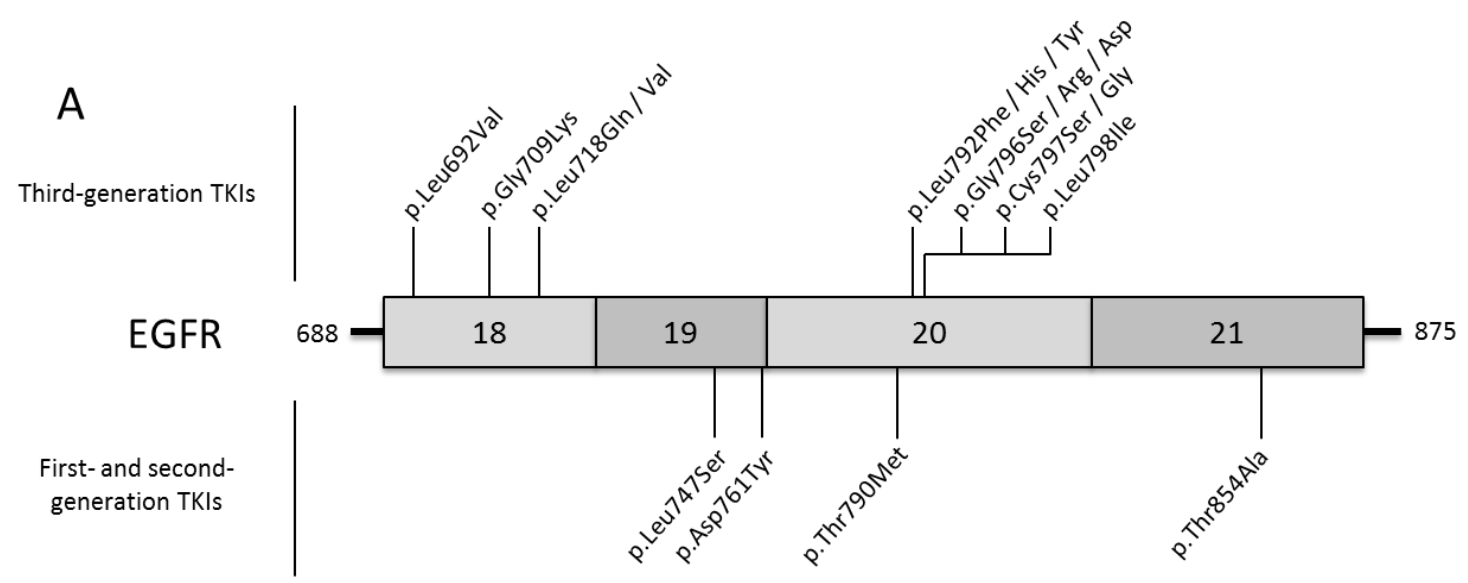

B

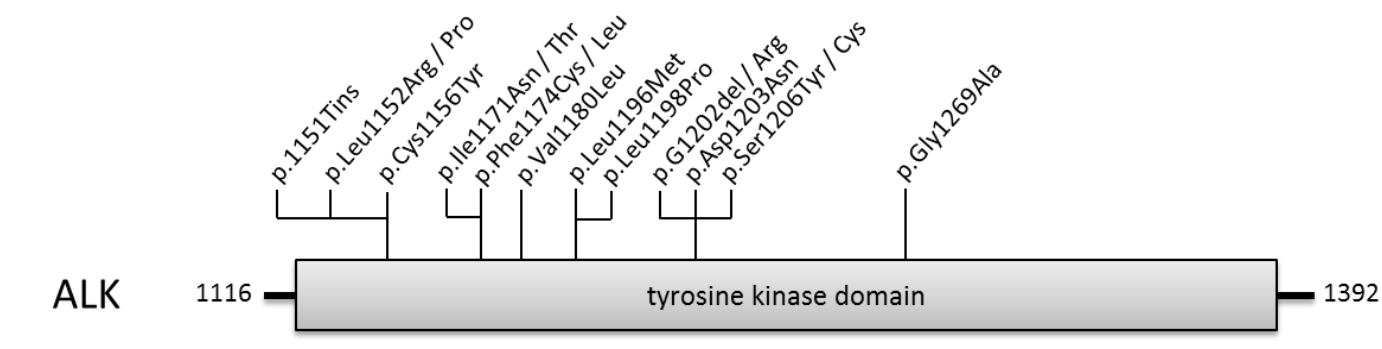

C

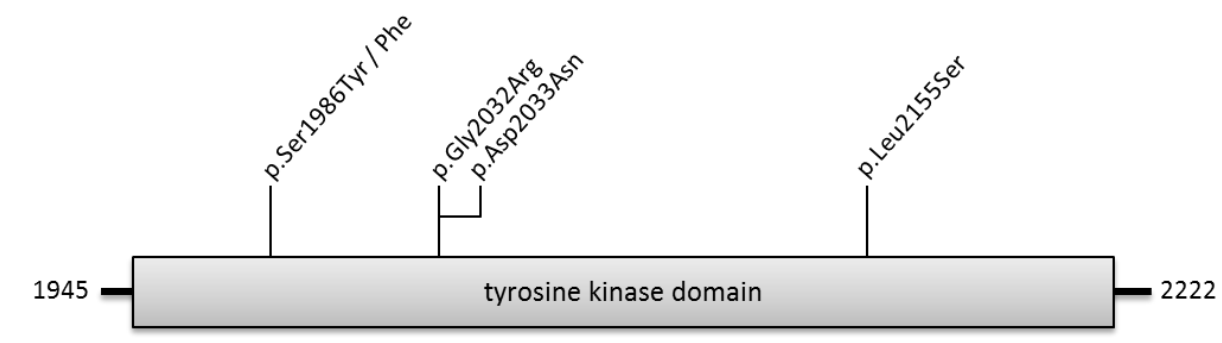

Figure 1. Resistance mutations in EGFR, ALK, and ROS1 drivers. (A) Description and gene location of EGFR resistance mutations to first-second and to third EGFR-TKIs; (B) description and gene location of ALK Tyrosine kinase resistance mutations to ALK inhibitors described for ALK fusions; (C) description and gene location of ROS1 Tyrosine kinase resistance mutations to ROS1 inhibitors described for ROS1 fusions.

\section{Resistance to Third-Generation EGFR-TKI}

Unfortunately, as described for the other EGFR-TKIs, resistances to osimertinib ultimately develop after a median PFS of 9.6 months [42]. Mechanisms involved in this resistance are not fully understood and appeared to be as heterogeneous as those described for first and second-generation EGFR-TKIs.

Osimertinib resistance can be divided into EGFR dependent and EGFR independent mechanisms. The first resistance mechanism identified in patients was the tertiary EGFR mutation p.Cys797Ser which directly targets the EGFR fixation site of osimertinib [44]. Tumor cells are resistant to all EGFR TKIs when the EGFR p.Cys797Ser and p.Thr790Met resistance mutations are located on the same allele, i.e., in cis-position. However, when these mutations are located in trans-position, a combination of first- and third-generation EGFR-TKIs could be administrated [45]. Other resistance 
EGFR mutations (e.g., EGFR p.Leu692Val, p.Glu709Lys, p.Leu718Gln/Val, p.Leu792Phe/Tyr/His, p.Gly796Asp/Ser/Arg, p.Cys797Gly, p.Leu798Ile) [46-48] (Figure 1A) and EGFR amplification have been described as alternative resistance mechanisms.

EGFR independent resistance mechanisms consist in activation of alternative pathways through different kinds of mutations (e.g., BRAF p.Val600Glu, KRAS or NRAS exon 2-3-4, PIK3CA p.Glu545Gln, $A K T, P T E N$, or CTNNB1) or gene amplifications (mainly EGFR, ERBB2, MET, FGFR1, KRAS, NRAS, or PIK3CA) [49].

Moreover, cellular changes were described as EGFR-TKIs resistance mechanisms. For instance, SCLC transformation was associated with resistance both to first-generation TKI and third-generation EGFR-TKI [50]. Phenotypic alterations, EMT and the acquisition of stem cell features are also consistent mechanisms of resistance to all EGFR-TKIs.

Third-Generation EGFR-TKI as First-Line Treatment of EGFR Mutated NSCLC

The FLAURA study [51] is a phase III clinical trial which compared osimertinib to first-generation EGFR-TKI in first line treatment of EGFR mutated NSCLC. This study only included common EGFR mutated lung cancers. The median PFS was significantly increased with osimertinib compared to first generation EGFR-TKI (18.9 vs. 10.2 months, respectively) whereas the ORR remained similar ( $80 \%$ vs. $76 \%)$.

No clinical trial has compared osimertinib as a first-line treatment versus first-generation EGFR-TKI in the first-line treatment until disease progression followed by osimertinib treatment in second-line for patients with EGFR p.Thr790Met mutation-positive NSCLC. Actually less than a half of patients treated with first or second generation EGFR-TKI have access to osimertinib in the second line thanks to the identification of the EGFR p.Thr790Met. Osimertinib in the first line has a favorable safety profile and may allow more patients to benefit from treatment. However, up-front resistance and secondary resistance are only partially explored raising the question of second-line treatment in case of acquired resistance. Furthermore, second generation EGFR-TKI was compared to osimertinib.

\section{Allosteric Inhibitors of EGFR}

Most of EGFR TKIs target the ATP-binding site of the tyrosine kinase domain of EGFR. The low selectivity of these treatments leads to additional toxicities. Moreover, the efficacy of these treatments can be altered by mutations within the ATP binding site (i.e., Thr790 or Cys797). For these reasons, allosteric EGFR inhibitors with different mechanism of action have been developed. For instance, EAI045-that binds an allosteric site outside the ATP-binding site-significantly and selectively modulates kinase activity in EGFR-TKIs resistant mutants. Allosteric EGFR inhibitors targeting the EGFR p.Cys797Ser resistance mutation are considered by some authors as fourth-generation EGFR-TKIs.

\subsubsection{BRAF}

BRAF mutations occur in 2 to $8 \%$ of patients with NSCLC [16,52]. The BRAF exon 15 p.Val600Glu activating mutation accounts for $50 \%$ of all $B R A F$ mutations. Other alterations are found in the exons 11 and 15, and are divided into activating (i.e., p.Gly469X, p.Leu597Arg, or p.Lys601Glu) or impaired mutations (i.e., p.Gly466Val, p.Asp594X, p.Gly596Cys) [53]. It results in the activation of the MAPK pathway through an activation of ERK signaling. Impaired mutants have decreased BRAF kinase activity but activate the MAPK pathway through the activation of CRAF signal transduction.

As expected from melanoma data, single BRAF inhibitors (i.e., vemurafenib or dabrafenib) induce cell cycle arrest and apoptosis in p.Val600Glu mutated-NSCLC [53]. Several case reports showed partial or complete response after single-BRAF inhibitor treatment [54], despite short median PFS and OS (5 and 10.8 months, respectively) [55].

The most recent advance in daily clinical practice for metastatic BRAF mutated-NSCLC is the association of a BRAF inhibitor dabrafenib with a MEK inhibitor trametinib. In a phase 2 trial, 
the association of dabrafenib and trametinib was assessed in first line treatment of $B R A F$ p.Val600Glu metastatic NSCLC and showed an ORR of 64\% [56]. Since June 2017, this combined therapy is now approved by the FDA as first line therapy for patients with BRAF p.Val600Glu mutation-positive metastatic NSCLC [57]. Non-p.Val600Glu mutations represents approximately half of all BRAF mutated NSCLC. In-vitro study confirmed that several non-p.Val600Glu BRAF mutations in exon 11 and 15 could also be sensitive to dabrafenib and trametinib combination [58].

\subsubsection{MET}

The MET receptor tyrosine kinase is part of aberrant signaling networks in many cancer types, including lung cancer. MET dysregulations mainly involve gene amplifications and MET exon 14 splice site mutations (MET $\triangle 14)$ that are markers of response to MET inhibitors. Both are not exclusive. Other type of MET mutations, including point mutations involving the MET TK domain, are rare and their value as markers of response to inhibitors needs to be evaluated for each case [59].

MET $\triangle 14$ alterations are detected in approximately $3-4 \%$ of lung adenocarcinomas, and MET amplification from 1 to $5 \%$ [60]. In patients with pulmonary sarcomatoid carcinomas that are not RAS mutated, MET $\Delta 14$ is a recurrent [61]. MET is involved in oncogenic signaling, metastasis, and development of secondary resistance-notably to first-generation EGFR-TKIs [62]. Basically, there are two situations were MET testing could help treatment decision: patients with a non-KRAS, BRAF, EGFR, or HER2 tumor for which the identification MET as a driver could lead to specific treatment and patients with EGFR mutated tumors secondary resistance. In these two situations, MET inhibitors have been tested in combination with EGFR TKIs: in a randomized EGFR wild type cohort of 111 patients, PFS was significantly improved in the cabozantinib group (4.3 months), erlotinib plus cabozantinib group (4.7 months) compared with erlotinib alone (1.8 months) [63]. Another randomized phase II trial tested the combination of onartuzumab - an antibody binding to the extracellular domain of c-Met- in combination with erlotinib. PFS and OS were improved in the MET-positive population [64]. Responses to crizotinib have been observed in a small study and is under trial on larger cohorts [62]. Met inhibition showed clinical benefit for patients with MET 14 -driven NSCLC and large clinical trials directed toward MET $\triangle 14$ may validate selected therapy for those patients. MET $\triangle 14$ testing should then be part of lung cancer testing. The high variability of splicing alterations may render interpretation of unknown variants challenging. Splice prediction algorithms may be of help but in some cases, RNA analysis to identify the MET $\triangle 14$ mRNA could be necessary to validate the functional impact of the alteration. Some NGS fusion panels integrate MET analysis for that specific purpose [65].

\subsubsection{KRAS}

KRAS activating mutations are found in nearly $30 \%$ of samples and is up to now used as an exclusion biomarker. KRAS mutated tumors are more frequent in smokers and rarely harbor other druggable drivers. Co-mutations include PI3KCA and STK11 but the use of PI3K or mTOR inhibitors has not led to any recommendations. Patients with KRAS mutated tumors do not benefit from targeted therapy. Trials testing the impact of MEK inhibitors have failed to demonstrate any benefit [66]. Drugs that specifically block the most frequent KRAS mutation in lung cancer (p.Gly12Cys) are under development. These drugs target the KRAS p.Gly12Cys mutation that is linked to tobacco exposure. Finally, immunotherapy may also be a treatment option for patients with KRAS mutated tumors. Different results suggest that smoking status may be a predictive marker for survival benefits to immunotherapy, possibly due to the existence of a high mutation load in tumors from smokers.

\subsubsection{PI3KCA}

It is likely that PI3KCA might become by itself a predictive marker. However, the presence of PIK3CA/AKt/mTOR pathway co-mutation was shown to confer resistance to gefitinib in EGFR mutated NSCLC. Larger series are needed to confirm this finding. 


\subsection{Fusion Testing}

\subsubsection{ALK}

ALK rearrangements are involved in 3-7\% of NSCLC. In 2007, the first described fusion-gene was located in the short arm of chromosome 2 as the result of a fusion between echinoderm microtubule-associated protein-like 4 (EML4) and ALK genes [67]. Other fusion partners-such as KLC1, TFG, or KIF5B - were then identified in NSCLC. ALK-rearrangements lead to a constitutively active oncogenic fusion protein which signals through different signaling pathways such as MAPK or JAK-STAT. In addition to gene fusions, ALK point mutations and amplifications have also been described but the link between these alterations and the response to ALK inhibitors is not well documented.

ALK fusion should be part of lung cancer routine diagnosis for all stage IV patients as it is easy to detect using immunohistochemistry (IHC) as a screening tool. No restriction to a specific group of patients should be done.

Three generations of ALK inhibitors are now available for the treatment of ALK-rearranged NSCLC. In a phase 3 clinical trial comparing first-generation ALK inhibitor, crizotinib vs. chemotherapy in first line treatment in ALK-rearranged NSCLC, median PFS was significantly longer with crizotinib compared with chemotherapy (10.9 vs. 7.0 months, respectively). Moreover, ORR was also increased with crizotinib (74\% and $45 \%$, respectively) [68]. Crizotinib is now considered as a standard first line treatment of ALK-rearranged NSCLC.

Second- and third-generation ALK inhibitors were developed to overcome several resistance mutations to first-generation ALK inhibitor. Second-generation ALK inhibitors, ceritinib, and alectinib, are now both approved as a first line treatment of ALK-rearranged NSCLC. The ASCEND-4 phase III clinical trial compared ceritinib vs. platinum-based chemotherapy for first-line therapy of ALK-rearranged NSCLC. The median PFS was significantly increased in the ceritinib group compared with chemotherapy group (16.6 vs. 8.1 months, respectively) [51]. Moreover, ceritinib significantly improves PFS of patients with crizotinib-refractory ALK-rearranged NSCLC [69]. In the same way, the 12-month event-free survival rate was significantly increased with alectinib compared with crizotinib in the first line treatment of ALK-rearranged NSCLC (68.4\% vs. 48.7\%, respectively). Unlike crizotinib and ceritinib, alectinib is also effective in central nervous system progression [70]. Lorlatinib is the third-generation ALK and ROS1 inhibitor. A phase-3 clinical trial (NCT03052608) is now recruiting patients to compare lorlatinib and crizotinib in the first line treatment of advanced ALK-rearranged NSCLC.

Recent studies have addressed the impact of ALK fusion variants on response to ALK inhibitors. Indeed, in vitro studies suggested that sensitivity to ALK inhibitors could differ between variants. In vivo, the most frequent variants are V1 and V3. No significant difference was found for OS, PFS, and progression pattern between patients with tumors harboring V1 or V3 fusion transcripts. In patients treated in third line by lorlatinib after first- and second-generation ALK inhibitors, V3 was associated with longer PFS. However, this result needs to be validated in larger series. The main difference between ALK variants is the rate of secondary resistance mutations with more mutations and more p.Gly1202Arg mutation detected in V3 variants. This could impact the choice of second-line TKI treatment.

Finally, the choice of first line treatment should take into account brain metastasis and be determined by balancing efficacy and toxicity as long as there is no clear molecular evidence to select one or the other.

\subsubsection{Resistance to ALK-Inhibitors}

As described for EGFR-TKIs, almost all patients treated with ALK-inhibitors ultimately relapse on therapy, generally within 12 to 24 months. Mechanisms leading to the resistance to ALK inhibitors are either ALK-dependent or ALK-independent mechanisms. Different ALK tyrosine 
kinase domain mutations (exons 20 to 29) were described, leading to a constitutive activation of ALK (e.g., Leu1196Met, p.Gly1269Ala, and then p.Gly1202Arg, p.Ser1206Tyr, p.Val1180Leu, p.Cys1156Tyr) (Figure 1B) [67]. ALK resistance mutations were firstly described after treatment with crizotinib, but seem to be more common after treatment with second generation ALK-inhibitors [71]. Second generation ALK-inhibitors overcome some crizotinib resistance mutations (e.g., p.Leu1196Met or p.Gly1269Ala) but fail to show activity against $A L K$ p.Gly1202Arg mutated tumors. On the other hand, the ALK-inhibitor resistance may be induced by activation of alternative downstream pathways as amplification of tyrosine kinase receptors genes such as EGFR, ERBB2, or CKIT [72]. In addition, EMT has also been described as a resistance mechanism to ALK-inhibitors. The identification of secondary resistance mutation should drive sequential therapy of different generations of ALK-inhibitors. Indeed, inhibitor efficiency depends on the presence of resistance mutations. Lorlatinib is the only inhibitor to be efficient in case of p.Gly1202Arg. Finally, the identification of an ALK independent mechanism may point out another druggable driver.

\subsubsection{ROS1}

ROS1 rearrangements are uncommon fusion genes occurring in 1-2\% of NSCLC, approximately half as common as ALK-rearrangements [73]. ROS1 fusion were identified as potential driver mutations in NSCLC, leading to constitutive kinase activity [73]. Patients with ROS1-rearranged and ALK-rearranged tumors share similar clinical profiles: they are significantly younger and more likely to be non-smokers compared to ROS1 negative group, with a higher prevalence in Asians. Metastatic patterns are slightly different between both groups with more brain metastases and extrathoracic metastatic sites for AKL-rearranged tumors [74]. Crizotinib demonstrated its efficiency against ROS1-rearranged patients, in two independent phase II prospective studies, with a concordant ORR of $72 \%$ and $70 \%$ in respectively two cohorts of 50 and 53 ROS1 positive patients and a median PFS of 19.2 and 15.9 months respectively [4,75]. Tolerance is generally consistent with the safety profile evaluated in ALK-positive patients. ROS1 screening should be tested upfront as crizotinib is now approved for first line treatment. However, FISH is often performed only in the case of negativity of first line tests.

PFS are often longer in patients with ROS1 rearranged tumors as compared to ALK and only a few mutations were described in ROS1 tyrosine kinase domain as mechanism of crizotinib resistance. In addition upregulation of bypass signaling pathways have been reported. ROS1 p.Gly2032Arg and p.Asp2033Asn remain the most frequently observed crizotinib resistance mutations [74]. ROS1 p.Ser1986Phe and p.Ser1986Tyr mutations were also described to confer resistance to crizotinib but remain sensitive to lorlatinib [76] (Figure 1C).

\subsubsection{RET}

RET fusions were identified in a small subset of NSCLC (around 1\% of frequency). According to a meta-analysis on 6899 NSCLC, RET fusion gene occurs at significantly higher frequencies in young ( $<60$ years old) female, Asian, and nonsmoker patients. These features are shared with other fusion genes. No impact was detected on prognosis and TNM stage of tumor [77]. No specific targeted drug is yet available for RET-rearranged tumors. However, multikinase inhibitors sunitinib and alectinib are approved, with a limited benefit in term of response (16 to 47\%) and PFS (two to seven months). Carbozantinib and vandetanib were also tested in clinical trials; PFS and OS were 5 and 10 months, respectively. Recently, a resistance mutation (RET p.Ser904Phe) was identified in a CCDC6-RET fusion tumor in a patient that developed secondary resistance to vandetanib suggesting that similar type of resistance mechanisms as for other targeted drugs can occur [78]. Specific drugs are expected soon with better effects $[79,80]$. Molecular routine screening of RET rearrangement in front line might become mandatory in the future, RET fusions could be better identified along with other hotspot fusions using NGS fusion panels. 


\subsubsection{NTRK}

NTRK1 fusions have recently been described as driver in a subpopulation of lung cancers, about 0.1-3\% [81,82]. Despite this low frequency, NTRK fusions are an interesting target because of initial reports of NRTK-inhibitors showing a dramatic tumor response and suggesting that the selective inhibition of this pathway is a promising therapeutic approach $[82,83]$. Entrectinib-a multikinase inhibitor- and LOXO-101-a pan-NTRK inihibitor-are currently under clinical evaluation [83]. The existence of targeted therapies makes NTRK fusions a promising biomarker that should be investigated thanks to NGS pan-fusion gene panels or IHC.

\subsubsection{NRG1}

NRG1 fusions have emerged as uncommon alterations in lung adenocarcinomas and especially in invasive mucinous lung adenocarcinoma (IMA). NRG1 fusions activates the ERBB2/ERBB3 signaling pathway [84]. A durable response with afatinib was first reported in a patient harboring a NRG1 gene fusion [85]. However, others reported that response was not achieved with afatinib in four NRG1-rearranged patients, while an exceptional response was observed with anti-ERBB3 monoclonal antibody therapy [86]. Those data suggest that ERBB3 inhibition may be more optimal than ERBB2 inhibition, but larger series are required. So far, NRG1 fusions are not tested in clinical routine, however NGS fusion panels and RNAseq strategies allow NRG1 fusion detection. In non-smokers with IMA, NRG1 fusions should be tested as the identification of this driver has a direct clinical impact.

\subsubsection{Gene Fusion Detection}

One of the most remarkable advances relative to NSCLC personalized medicine is the ability to detect fusion genes with targeted panels using RNA. Until now, ALK, RET, and ROS1 rearrangements were analyzed using either IHC or/and FISH methods. However, FISH is time consuming, expensive and difficult to interpret, thus only $A L K$ is constantly tested in routine. For rare rearrangements, FISH is secondarily performed for ROS1 or RET rearrangements when mutations are negative. In daily practice, the low quantity of tumor material does not always allow an extensive study of all putative targets, successively. New NGS fusion panels are now available, offering the possibility of studying rearrangements from low RNA inputs. Basically differences rely on the possibility of detecting all fusion partners or a subset of frequent partners and on the number of fusions analyzed [87]. These data suggest that NGS may provide an effective and accurate alternative to FISH testing for the detection of $A L K$ and ROS1 rearrangements in clinical routine, and offers the possibility of large screening of other rare rearrangements with potential clinical value [87-90]. Fusion panels work on RNA, they have been optimized for low inputs FFPE-RNA, however quality needs to be checked and long-time storage of FFPE samples is not recommended. Some systems allow the use of total nucleic acids (combined DNA and RNA extraction), enabling mutation testing and subsequent fusion testing on a unique sample.

\subsection{Technical Evolution in Clinical Molecular Testing}

\subsubsection{From Single Gene to Multi-Gene Testing/Panels}

Single gene testing or restricted hotspot testing methods were developed to screen for EGFR p.Leu858Arg mutation or deletions within the exon 19. The identification of rare alterations with a validated clinical impact such as rare $E G F R, M E T$, or $B R A F$ variants enlarged testing coverage and led to the implementation of the clinics high-throughput tests. NGS and especially targeted NGS were rapidly validated for sample FFPE samples and implemented in diagnostic laboratories. For lung cancer, there are easy-to-use and affordable commercial panels that differ slightly but cover the important targets-EGFR, KRAS, BRAF, and MET. These panels are referred to as targeted NGS panels as they focus on hotspot regions and frequently altered genes, with a direct and known consequence on therapy, diagnosis or prognosis. These panels have been validated by various studies: Shao et al. showed a concordance rate of $100 \%$ on 61 tumor samples previously profiled. Lih et al. compared 
380 mutations previously identified in cell lines: the assay achieved sensitivities of $100 \%$ for 64 single nucleotide variants SNVs, nine SNVs at homopolymer regions, and 11 large indels, $83.33 \%$ for six indels, and $93.33 \%$ for 15 indels at homopolymer regions. Thus, NGS can now be considered a first line technology [91-94].

NGS time workflow from sample to results is longer than single gene testing and at some point, clinicians might wonder why they should wait for NGS data while EGFR testing is necessary to treat patients. If NGS provides a wider analysis, results are available within a week. To shorten delays for hotspot alterations, prescreening with mutant specific probes can be part of the testing pipeline in order to provide a quick answer for first line treatment. Then, NGS data can be included in the molecular report.

What can we expect from NGS data? We recently showed in a large series of lung cancer patients that besides allowing the identification of $E G F R, K R A S$, and $B R A F$ mutations, NGS identified a potential driver in $36 \%$ of patients (FGFR, ERBB2, AKT, MAP2K1, STK11 ... ) [14,94-96]. Numerous experimental drugs are under development [97], and a large molecular characterization could be mandatory in the coming years.

Many different panels are being developed, including more genes, tumor mutation load (TML), MSI status determination, and fusions. These comprehensive panels will bring answers and questions. Large NGS panels drive more information and more questions when variants of unknown significance VUS, of unknown predictive value, of predictive value in another cancer type are identified in genes that are potential driver [98]. The link between detection and clinics is not always easy, however international databases help to provide information for each variant identified, combining the functional effect on proteins and response to treatment. Methods for high-throughput functional evaluation are being developed and could offer a fast and accurate improvement for data interpretation [99].

The increase in the number of genes in panels raises different problems-technical issues: panel validation, quality assessment and quality control may be tough; clinical issues: the management of VUS, the comprehensive analysis of network of mutations, and the management of incidental findings. Notably, it is now possible to perform a somatic exome in clinical routine. Genetic counseling should be mandatory before somatic exome sequencing in patients with lung cancer so patients may be advised on the possibility of incidental findings and the options for future management and eventually family planning (Figure 2).

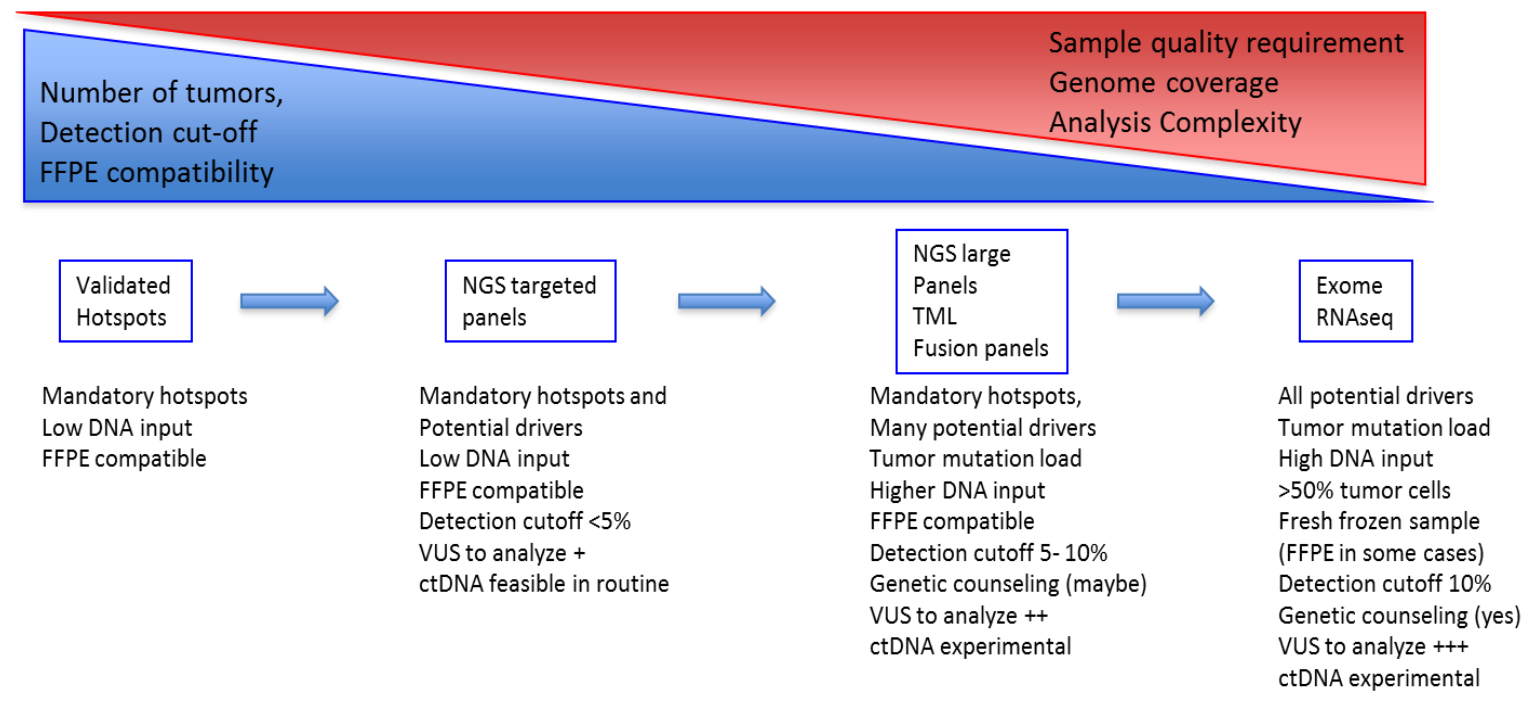

Figure 2. Lung cancer molecular screening options. Figure 2 shows the different technical options developed to identify oncogene drivers in lung cancer from single gene tests to WES including methods' specificities, mutation cut-off, genomic coverage/panel size, and sample requirements. 


\subsubsection{From Tissue Testing to Circulating DNA}

The emergence of secondary mutations and treatment resistance was seen for all targeted therapies used in lung cancer treatment monitoring as a major challenge for oncologists as evolution of tumor cell genetic profiles and molecular heterogeneity have been linked to resistance. To facilitate molecular monitoring and to limit iterative biopsies, circulating tumor DNA (ctDNA) can be used to identify tumor genetic alterations.

The existence of circulating nucleic acids has been known since 1948 [100], but their potential applications have only been identified in the last few years. Circulating cell free DNAs (ccfDNA) are produced by cell apoptosis, necrosis, or active excretion, and circulate freely in the blood. The recent identification of a fraction originating from the tumor - the circulating tumor DNA (ctDNA) - in patients with malignancies enlarged dramatically the potential use of ccfDNA as a predictive biomarker. Different methods allow the detection of tumor mutation in ccfDNA, and NGS has been adapted to analyze liquid biopsy specimens with good accuracy [101].

Three types of biomarkers can be detected in blood: ctDNA, circulating tumor cells (CTC), and exosomes [102,103]. CtDNA is the most promising of these biomarkers, as the easiest to handle in clinical routine. Various applications of ctDNA are being developed, for diagnostic, prognostic and theranostic purposes. Theranostic value is the most evident application in clinical routine. Numerous studies have been performed to compare ctDNA analysis to match tumor samples: sensitivity is approximately $50-70 \%$ and specificity $90-99 \%$ [104,105] depending on the studies [106]. The sensitivity is related to the low amount of ctDNA among ccfDNA and to the global amount of ccfDNA that challenges the limit of detection of sequencing technologies. Bioinformatic methods are being developed to discriminate a true mutation at low frequency in ctDNA from background noise [101] and sequencing methods were adapted to improve sensitivity [107]. However, ctDNA cannot be detected in $20-30 \%$ of patients. The absence of circulating DNA in some patients might also be clinically meaningful as many studies have shown that no or low ctDNA at diagnosis was related to a better outcome and ctDNA decrease upon treatment is linked to response, PFS and OS.

The second major application is the detection of resistance mutations during targeted treatment: ctDNA can avoid the inherent disadvantages of tissue rebiopsy. When patients progress on first or second line EGFR TKI therapy, the alternative is to look for the EGFR p.Thr790Met mutation and switch to a third generation TKI. Liquid biopsy is a good surrogate to re-biopsy and might reflect tumor heterogeneity [108]. It should be proposed as the first line option to monitor EGFR-TKI resistance but re-biopsy is recommend if ctDNA testing is negative [105]. Resistance mutations to ALK-inhibitors can also be detected on ctDNA: in a cohort of 31 patients, McCoach et al. showed that 16 samples (53\%) contained 1-3 ALK resistance mutations [109]. ctDNA could, in the future, have wider clinical application as a prognostic marker and a marker of response to treatment independent of treatment type [110]. A recent study on 177 NSCLC highlighted that high ctDNA concentration was and independent prognostic factor for progression-free survival and overall survival. However, concentration changes during treatment did not correlate with radiological CT response [111]. We analyzed prospectively the clinical impact of ctDNA independently of molecular profiles and first line treatment, we found that ctDNA at baseline was an independent marker of poor prognosis, with a median OS of 13.6 versus 21.5 months and a median PFS of 4.9 versus 10.4 months. At first evaluation (E1) after treatment initiation, residual ctDNA was an early predictor of treatment benefit as judged by best radiological response and PFS [112].

\subsubsection{Predictive Markers of Response to Immune Checkpoint Inhibitors, Focus on Genetic Determinants}

Recent changes in the treatment of patients with advanced lung cancer include the use of immune checkpoint inhibitors (ICIs). Treatment with ICIs can lead to durable responses in some patients but molecular determinants are still being investigated to better select responders. Sensitivity to ICIs is mainly multifactorial, involving tumor genetics background, immune cell infiltrates, and the level of 
immune-modulators such as PD-L1 or PD1 expression. However, we'll focus on genetic determinants related to improved survival in lung cancer patients treated with ICIs.

The hypothesis that tumor immune response is activated by antigenic specific peptides and that at least a subgroup of these tumor specific antigens originate from tumor mutations lead to investigating the impact of tumor mutational load on response to ICIs. Indeed, responsiveness to ICIs was first documented in highly mutated cancers such as melanoma and tobacco-related lung tumors $[113,114]$ pointing out that tumor mutation burden, neoantigen load, and response to ICIs were possibly linked.

\subsubsection{Driver Mutations as Predictive Markers}

Indeed there are evidences that non-smokers with EGFR mutated or ALK fusion positive tumors do not do well with ICIs. Patients with an identified driver EGFR, ALK or ROS1 should not receive first line ICIs even though tumor cells may express high PD-L1. Upregulation of PD-L1 is not rare in EGFR mutated or ALK rearranged lung tumors [115] and was related to activation of ERK or mTOR signaling [116]. In second line treatment if the EGFR p.Thr790Met mutation is not present patients should be offered chemotherapy [117]. A recent study showed that after EGFR-TKI relapse, ICI treatment was associated with a 2.1 and 1.3 month PFS for EGFR Thr790Met-negative and Thr790Met-positive patients [118]. Moreover, ICIs do not improve OS compared to docetaxel in this setting [119].

In smokers, KRAS and TP53 co-mutation could be predictive of response to immunotherapy. TP53 was shown to increase expression of immune checkpoints and was linked to interferon-gamma signature. Moreover, KRAS / TP53 mutated samples showed a favorable immune infiltrate and a higher mutation burden [120].

In contrast, LKB1/STK11 mutations in association or not with KRAS were related to a lack of response to immunotherapy [121]. This could be related to specific immune environment linked to LKB1/STK11 mutated tumors $[122,123]$.

\subsubsection{Tumor Mutational Load (TML) as a Predictive Marker}

In lung cancer, somatic mutation load was related to tobacco exposure and to a specific molecular smoking signature. Tobacco induced DNA damage is linked to mutation counts and subsequently to response to ICIs [124]. Recently, an ancillary study of the CheckMate 026 clinical trial explored TML predictive value in a population of lung cancer patients with a PD-L1 expression of $5 \%$ or more. The main result from this phase 3 trial was that nivolumab was not associated with significantly longer progression-free survival than chemotherapy. However, TML was assessed in a subgroup of patients using exome sequencing. PFS was longer in the subgroup of patients with high TML defined as $>243$ mutations per exome or $>8$ mutations $/ \mathrm{Mb}$ (median, 9.7 vs. 5.8 months; hazard ratio for disease progression or death, $0.62 ; 95 \% \mathrm{CI}, 0.38$ to 1.00 ). No difference was observed for OS. It was attributed to treatment crossover. No overlap was found between PD-L1 expression and TML however patients with both PDL1 $>50 \%$ and TML high experienced longer PFS.

Based on different studies, high TML seems predictive of response to ICIs, however some patients with low TML respond to treatment and some with high TML have short PFS.

TML is the surrogate marker of tumor neoantigen load (TNagL). Different studies have shown that neoantigen load can be estimated using algorithms that take into account various parameters, including peptide binding to patients' specific HLA isoforms. TNagL is much lower than TML with only a few neoantigens present even when TML is high [125]. High TML increases the chance that, at random, neoantigens are synthetized by tumor cells. Due to the importance of neoantigens in cancer immunotherapy, TNagL is an attractive biomarker to identify responders to ICIs.

\subsubsection{Quantification of Tumor Mutational Burden}

Although WES sequencing is actually the gold standard, TML was also investigated using NGS targeted panel. Different strategies have been tested and compared to WES data to validate TML 
by targeted NGS. Altogether, results showed that good correlations are obtained with WES if TML is determined using large comprehensive panel over $1 \mathrm{Mb}$. However, mutation cut-offs and a clear definition of low and high TML still need to be validated [126,127]. Finally, the identification of repair pathway defects such as MMR deficiency which is rare considering lung cancer and mutation in DNA polymerases POLE and POLD1 are surrogate markers of TML [126].

\section{Discussion and Conclusions}

While treatment decisions are determined by cancer stage, molecular alterations drive medical care for patients with advance stage lung tumors. Indeed, targeted therapies have proven to be effective therapeutic approaches and were related to treatment response in selected patients. Many reviews have discussed the clinical value of molecular alterations in lung cancer. However, the access to broad molecular screenings as part of routine care will change the clinical management of lung cancer patients in the near future. Small molecular subgroups of patients are identified with potential drivers and drugs are being developed (BRAF, RET, NTRKs, and NRG1). In parallel, recommendations concerning therapeutic sequences are changing (EGFR), molecular changes in the course of treatment need to be explored to identify secondary resistance alteration and adapt treatment (ALK ROS1) and immunotherapy brings new biomarkers to clinic. Molecular testing is required for all patients with advanced lung cancer to select the optimal first line treatments. Our challenge is to develop comprehensive molecular analyses to optimize treatment choices, combinations, or sequences at diagnosis and during follow-up. An example of lung cancer testing algorithm is summarized in Figure 3. Technological progresses in genomics have made it possible to provide comprehensive molecular tests using small biopsies and FFPE lung cancer tissues. NGS was applied to WES or RNA sequencing many research programs, it is now used as a diagnostic tool in clinical laboratories-but what can we expect from these technologies in care settings? We know sample requirements vary depending on the gene panel size and the type of analyses (DNA or RNA) but basic NGS molecular screenings are feasible in most cases.

Test performances will vary due to different sensitivities, specificities, sequencing depths, coverages and also due to the samples themselves (age, preservation conditions, tumor cellularity...). Test performance should be mentioned to the clinician and NGS workflows should be validated by external quality control programs.

Clinicians have to be aware that WES or large panels are not suitable for all samples. Due to lower sensitivity (150X coverage depth), WES may miss mutations in samples with low tumor cell content as compared to targeted panels ( $>1000 \mathrm{X}$ coverage depth) and subclonal populations may be more difficult to identify by exome sequencing.

NGS turnaround time ranges from a week to a few weeks. As a fast turnaround time may be critical to selecting first line treatment, multiplex PCR assays focusing on frequent mutations may still be useful. Indeed, in our experience, concordance between PCR assays and NGS is very good and PCR assays allow identification of EGFR and KRAS alterations within two days in more than $35 \%$ of samples [14].

Clinical interpretation of VUS identified by NGS platforms may be difficult. So the development of molecular tumor boards to discuss treatment options is mandatory for patients with tumors harboring VUS in known drivers and case reports should be collected and stored to educate and inform the community on the clinical impact of rare variants. Moreover, NGS - and especially WES-identifies many alterations in potential drivers, co-drivers, or tumor suppressors. The clinical interpretation of networks of alterations remains a hard task that has no validated clinical value yet.

Testing strategies must evolve to take into account the increase of new biomarkers, new targeted agents, new combination of drugs, and the necessity to not only diagnose but also monitor treatment responses. One might expect that next generation sequencing technologies will enable selection of the patients most likely to gain from targeted therapy and will ultimately inform clinical decision-making. 

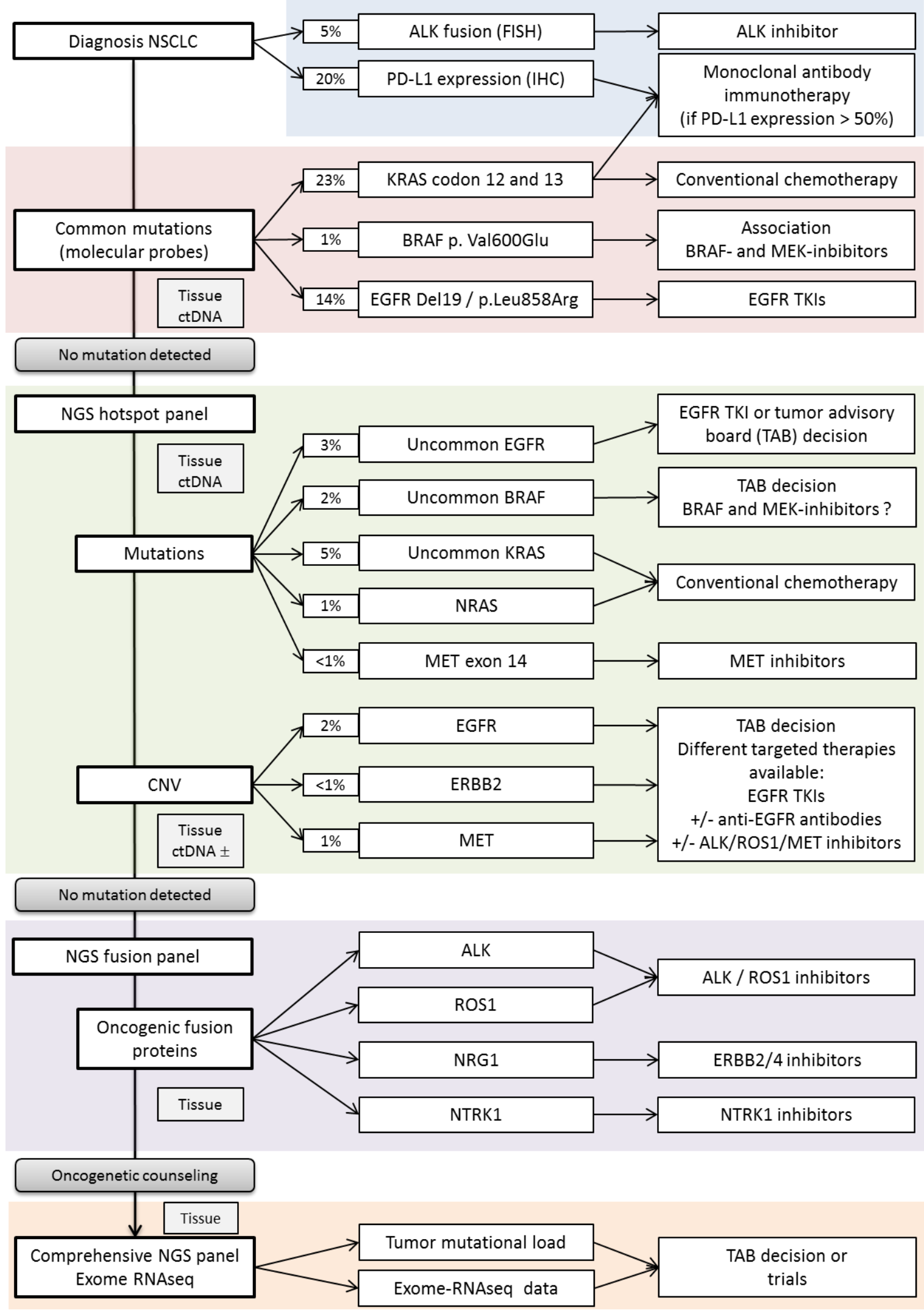

Figure 3. Lung cancer testing algorithm, an example in clinics. Figure 3 shows the different levels of molecular testing from single gene to WES, the expected findings, and potential clinical impacts. 
Author Contributions: Writing: S.G. and J.B.O.; Review \& Editing: H.B. and P.L.-P.; Supervision: H.B. and J.B.O.

Conflicts of Interest: Simon Garinet and Jean-Baptiste Oudart declare no conflict of interest. Hélène Blons declares occasional lectures and boards for Roche, AstraZeneca, Boehringer Ingelheim, Pfizer, BMS, and MSD. Pierre Laurent-Puig declares participation lectures and boards for Roche, AstraZeneca, Boehringer Ingelheim, Pfizer, BMS, MSD, MDS Serrono, Amgen, and Biocartis.

\section{References}

1. Siegel, R.; Naishadham, D.; Jemal, A. Cancer statistics, 2012. CA. Cancer J. Clin. 2012, 62, 10-29. [CrossRef] [PubMed]

2. Krishnan, V.G.; Ebert, P.J.; Ting, J.C.; Lim, E.; Wong, S.-S.; Teo, A.S.M.; Yue, Y.G.; Chua, H.-H.; Ma, X.; Loh, G.S.L.; et al. Whole-genome sequencing of Asian lung cancers: Second-hand smoke unlikely to be responsible for higher incidence of lung cancer among Asian never-smokers. Cancer Res. 2014, 74, 6071-6081. [CrossRef] [PubMed]

3. Deeb, K.K.; Hohman, C.M.; Risch, N.F.; Metzger, D.J.; Starostik, P. Routine Clinical Mutation Profiling of Non-Small Cell Lung Cancer Using Next-Generation Sequencing. Arch. Pathol. Lab. Med. 2015, 139, 913-921. [CrossRef] [PubMed]

4. Shaw, A.T.; Ou, S.-H.I.; Bang, Y.-J.; Camidge, D.R.; Solomon, B.J.; Salgia, R.; Riely, G.J.; Varella-Garcia, M.; Shapiro, G.I.; Costa, D.B.; et al. Crizotinib in ROS1-rearranged non-small-cell lung cancer. N. Engl. J. Med. 2014, 371, 1963-1971. [CrossRef] [PubMed]

5. Mayekar, M.K.; Bivona, T.G. Current Landscape of Targeted Therapy in Lung Cancer. Clin. Pharmacol. Ther. 2017, 102, 757-764. [CrossRef] [PubMed]

6. Gridelli, C.; Balducci, L.; Ciardiello, F.; Di Maio, M.; Felip, E.; Langer, C.; Lilenbaum, R.C.; Perrone, F.; Senan, S.; de Marinis, F. Treatment of Elderly Patients with Non-Small-Cell Lung Cancer: Results of an International Expert Panel Meeting of the Italian Association of Thoracic Oncology. Clin. Lung Cancer 2015, 16, 325-333. [CrossRef] [PubMed]

7. Girard, N. Optimizing outcomes in EGFR mutation-positive NSCLC: Which tyrosine kinase inhibitor and when? Future Oncol. Lond. Engl. 2018. [CrossRef] [PubMed]

8. De Leng, W.W.J.; Gadellaa-van Hooijdonk, C.G.; Barendregt-Smouter, F.A.S.; Koudijs, M.J.; Nijman, I.; Hinrichs, J.W.J.; Cuppen, E.; van Lieshout, S.; Loberg, R.D.; de Jonge, M.; et al. Targeted Next Generation Sequencing as a Reliable Diagnostic Assay for the Detection of Somatic Mutations in Tumours Using Minimal DNA Amounts from Formalin Fixed Paraffin Embedded Material. PLoS ONE 2016, 11, e0149405. [CrossRef] [PubMed]

9. Yates, L.R. Intratumoral heterogeneity and subclonal diversification of early breast cancer. Breast 2017, 34 (Suppl. 1), S36-S42. [CrossRef] [PubMed]

10. Cancer Genome Atlas Research Network. Comprehensive molecular profiling of lung adenocarcinoma. Nature 2014, 511, 543-550. [CrossRef]

11. Jordan, E.J.; Kim, H.R.; Arcila, M.E.; Barron, D.; Chakravarty, D.; Gao, J.; Chang, M.T.; Ni, A.; Kundra, R.; Jonsson, P.; et al. Prospective Comprehensive Molecular Characterization of Lung Adenocarcinomas for Efficient Patient Matching to Approved and Emerging Therapies. Cancer Discov. 2017, 7, 596-609. [CrossRef] [PubMed]

12. Imielinski, M.; Berger, A.H.; Hammerman, P.S.; Hernandez, B.; Pugh, T.J.; Hodis, E.; Cho, J.; Suh, J.; Capelletti, M.; Sivachenko, A.; et al. Mapping the hallmarks of lung adenocarcinoma with massively parallel sequencing. Cell 2012, 150, 1107-1120. [CrossRef] [PubMed]

13. Campbell, J.D.; Alexandrov, A.; Kim, J.; Wala, J.; Berger, A.H.; Pedamallu, C.S.; Shukla, S.A.; Guo, G.; Brooks, A.N.; Murray, B.A.; et al. Distinct patterns of somatic genome alterations in lung adenocarcinomas and squamous cell carcinomas. Nat. Genet. 2016, 48, 607-616. [CrossRef] [PubMed]

14. Legras, A.; Barritault, M.; Tallet, A.; Fabre, E.; Guyard, A.; Rance, B.; Digan, W.; Pecuchet, N.; Giroux-Leprieur, E.; Julie, C.; et al. Validity of targeted next-generation sequencing in routine care for identifying clinically relevant molecular profiles in non-small-cell lung cancer: Results of a 2-year experience on 1343 samples. J. Mol. Diagn. 2018. [CrossRef] [PubMed] 
15. Yatabe, Y.; Kerr, K.M.; Utomo, A.; Rajadurai, P.; Tran, V.K.; Du, X.; Chou, T.-Y.; Enriquez, M.L.D.; Lee, G.K.; Iqbal, J.; et al. EGFR mutation testing practices within the Asia Pacific region: Results of a multicenter diagnostic survey. J. Thorac. Oncol. 2015, 10, 438-445. [CrossRef] [PubMed]

16. Barlesi, F.; Mazieres, J.; Merlio, J.-P.; Debieuvre, D.; Mosser, J.; Lena, H.; Ouafik, L.; Besse, B.; Rouquette, I.; Westeel, V.; et al. Biomarkers France contributors Routine molecular profiling of patients with advanced non-small-cell lung cancer: Results of a 1-year nationwide programme of the French Cooperative Thoracic Intergroup (IFCT). Lancet Lond. Engl. 2016, 387, 1415-1426. [CrossRef]

17. Kris, M.G.; Johnson, B.E.; Berry, L.D.; Kwiatkowski, D.J.; Iafrate, A.J.; Wistuba, I.I.; Varella-Garcia, M.; Franklin, W.A.; Aronson, S.L.; Su, P.-F.; et al. Using multiplexed assays of oncogenic drivers in lung cancers to select targeted drugs. JAMA 2014, 311, 1998-2006. [CrossRef] [PubMed]

18. Tseng, C.-H.; Chiang, C.-J.; Tseng, J.-S.; Yang, T.-Y.; Hsu, K.-H.; Chen, K.-C.; Wang, C.-L.; Chen, C.-Y.; Yen, S.-H.; Tsai, C.-M.; et al. EGFR mutation, smoking, and gender in advanced lung adenocarcinoma. Oncotarget 2017, 8, 98384-98393. [CrossRef] [PubMed]

19. Kobayashi, Y.; Mitsudomi, T. Not all epidermal growth factor receptor mutations in lung cancer are created equal: Perspectives for individualized treatment strategy. Cancer Sci. 2016, 107, 1179-1186. [CrossRef] [PubMed]

20. Galli, G.; Corrao, G.; Imbimbo, M.; Proto, C.; Signorelli, D.; Ganzinelli, M.; Zilembo, N.; Vitali, M.; de Braud, F.; Garassino, M.C.; et al. Uncommon mutations in epidermal growth factor receptor and response to first and second generation tyrosine kinase inhibitors: A case series and literature review. Lung Cancer 2018, 115, 135-142. [CrossRef] [PubMed]

21. Grigoriu, B.; Berghmans, T.; Meert, A.-P. Management of EGFR mutated nonsmall cell lung carcinoma patients. Eur. Respir. J. 2015, 45, 1132-1141. [CrossRef] [PubMed]

22. Tu, H.-Y.; Ke, E.-E.; Yang, J.-J.; Sun, Y.-L.; Yan, H.-H.; Zheng, M.-Y.; Bai, X.-Y.; Wang, Z.; Su, J.; Chen, Z.-H.; et al. A comprehensive review of uncommon EGFR mutations in patients with non-small cell lung cancer. Lung Cancer 2017, 114, 96-102. [CrossRef] [PubMed]

23. O'Kane, G.M.; Bradbury, P.A.; Feld, R.; Leighl, N.B.; Liu, G.; Pisters, K.-M.; Kamel-Reid, S.; Tsao, M.S.; Shepherd, F.A. Uncommon EGFR mutations in advanced non-small cell lung cancer. Lung Cancer 2017, 109, 137-144. [CrossRef] [PubMed]

24. Beau-Faller, M.; Prim, N.; Ruppert, A.-M.; Nanni-Metéllus, I.; Lacave, R.; Lacroix, L.; Escande, F.; Lizard, S.; Pretet, J.-L.; Rouquette, I.; et al. Rare EGFR exon 18 and exon 20 mutations in non-small-cell lung cancer on 10117 patients: A multicentre observational study by the French ERMETIC-IFCT network. Ann. Oncol. 2014, 25, 126-131. [CrossRef] [PubMed]

25. Eck, M.J.; Yun, C.-H. Structural and mechanistic underpinnings of the differential drug sensitivity of EGFR mutations in non-small cell lung cancer. Biochim. Biophys. Acta 2010, 1804, 559-566. [CrossRef] [PubMed]

26. Bronte, G.; Rolfo, C.; Giovannetti, E.; Cicero, G.; Pauwels, P.; Passiglia, F.; Castiglia, M.; Rizzo, S.; Vullo, F.L.; Fiorentino, E.; et al. Are erlotinib and gefitinib interchangeable, opposite or complementary for non-small cell lung cancer treatment? Biological, pharmacological and clinical aspects. Crit. Rev. Oncol. Hematol. 2014, 89, 300-313. [CrossRef] [PubMed]

27. Morgillo, F.; Della Corte, C.M.; Fasano, M.; Ciardiello, F. Mechanisms of resistance to EGFR-targeted drugs: Lung cancer. ESMO Open 2016, 1, e000060. [CrossRef] [PubMed]

28. Keating, G.M. Afatinib: A review of its use in the treatment of advanced non-small cell lung cancer. Drugs 2014, 74, 207-221. [CrossRef] [PubMed]

29. Sequist, L.V.; Yang, J.C.-H.; Yamamoto, N.; O’Byrne, K.; Hirsh, V.; Mok, T.; Geater, S.L.; Orlov, S.; Tsai, C.-M.; Boyer, M.; et al. Phase III study of afatinib or cisplatin plus pemetrexed in patients with metastatic lung adenocarcinoma with EGFR mutations. J. Clin. Oncol. 2013, 31, 3327-3334. [CrossRef] [PubMed]

30. Wu, Y.-L.; Zhou, C.; Hu, C.-P.; Feng, J.; Lu, S.; Huang, Y.; Li, W.; Hou, M.; Shi, J.H.; Lee, K.Y.; et al. Afatinib versus cisplatin plus gemcitabine for first-line treatment of Asian patients with advanced non-small-cell lung cancer harbouring EGFR mutations (LUX-Lung 6): An open-label, randomised phase 3 trial. Lancet Oncol. 2014, 15, 213-222. [CrossRef]

31. Yang, J.C.-H.; Wu, Y.-L.; Schuler, M.; Sebastian, M.; Popat, S.; Yamamoto, N.; Zhou, C.; Hu, C.-P.; O'Byrne, K.; Feng, J.; et al. Afatinib versus cisplatin-based chemotherapy for EGFR mutation-positive lung adenocarcinoma (LUX-Lung 3 and LUX-Lung 6): Analysis of overall survival data from two randomised, phase 3 trials. Lancet Oncol. 2015, 16, 141-151. [CrossRef] 
32. Park, K.; Tan, E.-H.; O’Byrne, K.; Zhang, L.; Boyer, M.; Mok, T.; Hirsh, V.; Yang, J.C.-H.; Lee, K.H.; Lu, S.; et al. Afatinib versus gefitinib as first-line treatment of patients with EGFR mutation-positive non-small-cell lung cancer (LUX-Lung 7): A phase 2B, open-label, randomised controlled trial. Lancet Oncol. 2016, 17, 577-589. [CrossRef]

33. Paz-Ares, L.; Tan, E.-H.; O’Byrne, K.; Zhang, L.; Hirsh, V.; Boyer, M.; Yang, J.C.-H.; Mok, T.; Lee, K.H.; Lu, S.; et al. Afatinib versus gefitinib in patients with EGFR mutation-positive advanced non-small-cell lung cancer: Overall survival data from the phase IIb LUX-Lung 7 trial. Ann. Oncol. 2017, 28, 270-277. [CrossRef] [PubMed]

34. Chiu, C.-H.; Yang, C.-T.; Shih, J.-Y.; Huang, M.-S.; Su, W.-C.; Lai, R.-S.; Wang, C.-C.; Hsiao, S.-H.; Lin, Y.-C.; Ho, C.-L.; et al. Epidermal Growth Factor Receptor Tyrosine Kinase Inhibitor Treatment Response in Advanced Lung Adenocarcinomas with G719X/L861Q/S768I Mutations. J. Thorac. Oncol. 2015, 10, 793-799. [CrossRef] [PubMed]

35. Zhang, Y.; Wang, Z.; Hao, X.; Hu, X.; Wang, H.; Wang, Y.; Ying, J. Clinical characteristics and response to tyrosine kinase inhibitors of patients with non-small cell lung cancer harboring uncommon epidermal growth factor receptor mutations. Chin. J. Cancer Res. 2017, 29, 18-24. [CrossRef] [PubMed]

36. Wu, J.-Y.; Yu, C.-J.; Chang, Y.-C.; Yang, C.-H.; Shih, J.-Y.; Yang, P.-C. Effectiveness of tyrosine kinase inhibitors on "uncommon" epidermal growth factor receptor mutations of unknown clinical significance in non-small cell lung cancer. Clin. Cancer Res. 2011, 17, 3812-3821. [CrossRef] [PubMed]

37. Watanabe, S.; Minegishi, Y.; Yoshizawa, H.; Maemondo, M.; Inoue, A.; Sugawara, S.; Isobe, H.; Harada, M.; Ishii, Y.; Gemma, A.; et al. Effectiveness of gefitinib against non-small-cell lung cancer with the uncommon EGFR mutations G719X and L861Q. J. Thorac. Oncol. 2014, 9, 189-194. [CrossRef] [PubMed]

38. Ettinger, D.S.; Wood, D.E.; Aisner, D.L.; Akerley, W.; Bauman, J.; Chirieac, L.R.; D'Amico, T.A.; DeCamp, M.M.; Dilling, T.J.; Dobelbower, M.; et al. Non-Small Cell Lung Cancer, Version 5.2017, NCCN Clinical Practice Guidelines in Oncology. J. Natl. Compr. Cancer Netw. JNCCN 2017, 15, 504-535. [CrossRef]

39. Yang, J.C.-H.; Sequist, L.V.; Geater, S.L.; Tsai, C.-M.; Mok, T.S.K.; Schuler, M.; Yamamoto, N.; Yu, C.-J.; Ou, S.-H.I.; Zhou, C.; et al. Clinical activity of afatinib in patients with advanced non-small-cell lung cancer harbouring uncommon EGFR mutations: A combined post-hoc analysis of LUX-Lung 2, LUX-Lung 3, and LUX-Lung 6. Lancet Oncol. 2015, 16, 830-838. [CrossRef]

40. Finlay, M.R.V.; Anderton, M.; Ashton, S.; Ballard, P.; Bethel, P.A.; Box, M.R.; Bradbury, R.H.; Brown, S.J.; Butterworth, S.; Campbell, A.; et al. Discovery of a potent and selective EGFR inhibitor (AZD9291) of both sensitizing and T790M resistance mutations that spares the wild type form of the receptor. J. Med. Chem. 2014, 57, 8249-8267. [CrossRef] [PubMed]

41. Cross, D.A.E.; Ashton, S.E.; Ghiorghiu, S.; Eberlein, C.; Nebhan, C.A.; Spitzler, P.J.; Orme, J.P.; Finlay, M.R.V.; Ward, R.A.; Mellor, M.J.; et al. AZD9291, an irreversible EGFR TKI, overcomes T790M-mediated resistance to EGFR inhibitors in lung cancer. Cancer Discov. 2014, 4, 1046-1061. [CrossRef] [PubMed]

42. Jänne, P.A.; Yang, J.C.-H.; Kim, D.-W.; Planchard, D.; Ohe, Y.; Ramalingam, S.S.; Ahn, M.-J.; Kim, S.-W.; Su, W.-C.; Horn, L.; et al. AZD9291 in EGFR inhibitor-resistant non-small-cell lung cancer. N. Engl. J. Med. 2015, 372, 1689-1699. [CrossRef] [PubMed]

43. Mok, T.S.; Wu, Y.-L.; Ahn, M.-J.; Garassino, M.C.; Kim, H.R.; Ramalingam, S.S.; Shepherd, F.A.; He, Y.; Akamatsu, H.; Theelen, W.S.M.E.; et al. AURA3 Investigators Osimertinib or Platinum-Pemetrexed in EGFR T790M-Positive Lung Cancer. N. Engl. J. Med. 2017, 376, 629-640. [CrossRef] [PubMed]

44. Yu, H.A.; Tian, S.K.; Drilon, A.E.; Borsu, L.; Riely, G.J.; Arcila, M.E.; Ladanyi, M. Acquired Resistance of EGFR-Mutant Lung Cancer to a T790M-Specific EGFR Inhibitor: Emergence of a Third Mutation (C797S) in the EGFR Tyrosine Kinase Domain. JAMA Oncol. 2015, 1, 982-984. [CrossRef] [PubMed]

45. Niederst, M.J.; Hu, H.; Mulvey, H.E.; Lockerman, E.L.; Garcia, A.R.; Piotrowska, Z.; Sequist, L.V.; Engelman, J.A. The Allelic Context of the C797S Mutation Acquired upon Treatment with Third-Generation EGFR Inhibitors Impacts Sensitivity to Subsequent Treatment Strategies. Clin. Cancer Res. 2015, 21, 3924-3933. [CrossRef] [PubMed]

46. Tang, Z.-H.; Lu, J.-J. Osimertinib resistance in non-small cell lung cancer: Mechanisms and therapeutic strategies. Cancer Lett. 2018, 420, 242-246. [CrossRef] [PubMed]

47. Minari, R.; Bordi, P.; Tiseo, M. Third-generation epidermal growth factor receptor-tyrosine kinase inhibitors in T790M-positive non-small cell lung cancer: Review on emerged mechanisms of resistance. Transl. Lung Cancer Res. 2016, 5, 695-708. [CrossRef] [PubMed] 
48. Santarpia, M.; Liguori, A.; Karachaliou, N.; Gonzalez-Cao, M.; Daffinà, M.G.; D'Aveni, A.; Marabello, G.; Altavilla, G.; Rosell, R. Osimertinib in the treatment of non-small-cell lung cancer: Design, development and place in therapy. Lung Cancer (Auckl.) 2017, 8, 109-125. [CrossRef] [PubMed]

49. Tan, C.-S.; Kumarakulasinghe, N.B.; Huang, Y.-Q.; Ang, Y.L.E.; Choo, J.R.-E.; Goh, B.-C.; Soo, R.A. Third generation EGFR TKIs: Current data and future directions. Mol. Cancer 2018, 17, 29. [CrossRef] [PubMed]

50. Minari, R.; Bordi, P.; Del Re, M.; Facchinetti, F.; Mazzoni, F.; Barbieri, F.; Camerini, A.; Comin, C.E.; Gnetti, L.; Azzoni, C.; et al. Primary resistance to osimertinib due to SCLC transformation: Issue of T790M determination on liquid re-biopsy. Lung Cancer 2018, 115, 21-27. [CrossRef] [PubMed]

51. Soria, J.-C.; Tan, D.S.W.; Chiari, R.; Wu, Y.-L.; Paz-Ares, L.; Wolf, J.; Geater, S.L.; Orlov, S.; Cortinovis, D.; Yu, C.-J.; et al. First-line ceritinib versus platinum-based chemotherapy in advanced ALK-rearranged non-small-cell lung cancer (ASCEND-4): A randomised, open-label, phase 3 study. Lancet Lond. Engl. 2017, 389, 917-929. [CrossRef]

52. Lin, L.; Asthana, S.; Chan, E.; Bandyopadhyay, S.; Martins, M.M.; Olivas, V.; Yan, J.J.; Pham, L.; Wang, M.M.; Bollag, G.; et al. Mapping the molecular determinants of BRAF oncogene dependence in human lung cancer. Proc. Natl. Acad. Sci. USA 2014, 111, E748-E757. [CrossRef] [PubMed]

53. Baik, C.S.; Myall, N.J.; Wakelee, H.A. Targeting BRAF-Mutant Non-Small Cell Lung Cancer: From Molecular Profiling to Rationally Designed Therapy. Oncologist 2017, 22, 786-796. [CrossRef] [PubMed]

54. De Langen, A.J.; Smit, E.F. Therapeutic approach to treating patients with BRAF-mutant lung cancer: Latest evidence and clinical implications. Ther. Adv. Med. Oncol. 2017, 9, 46-58. [CrossRef] [PubMed]

55. Gautschi, O.; Milia, J.; Cabarrou, B.; Bluthgen, M.-V.; Besse, B.; Smit, E.F.; Wolf, J.; Peters, S.; Früh, M.; Koeberle, D.; et al. Targeted Therapy for Patients with BRAF-Mutant Lung Cancer: Results from the European EURAF Cohort. J. Thorac. Oncol. 2015, 10, 1451-1457. [CrossRef] [PubMed]

56. Planchard, D.; Smit, E.F.; Groen, H.J.M.; Mazieres, J.; Besse, B.; Helland, Å.; Giannone, V.; D'Amelio, A.M.; Zhang, P.; Mookerjee, B.; et al. Dabrafenib plus trametinib in patients with previously untreated BRAFV600E-mutant metastatic non-small-cell lung cancer: An open-label, phase 2 trial. Lancet Oncol. 2017, 18, 1307-1316. [CrossRef]

57. Odogwu, L.; Mathieu, L.; Blumenthal, G.; Larkins, E.; Goldberg, K.B.; Griffin, N.; Bijwaard, K.; Lee, E.Y.; Philip, R.; Jiang, X.; et al. FDA Approval Summary: Dabrafenib and Trametinib for the Treatment of Metastatic Non-Small Cell Lung Cancers Harboring BRAF V600E Mutations. Oncologist 2018. [CrossRef] [PubMed]

58. Noeparast, A.; Teugels, E.; Giron, P.; Verschelden, G.; De Brakeleer, S.; Decoster, L.; De Grève, J. Non-V600 BRAF mutations recurrently found in lung cancer predict sensitivity to the combination of Trametinib and Dabrafenib. Oncotarget 2017, 8, 60094-60108. [CrossRef] [PubMed]

59. Buzyn, A.; Blay, J.-Y.; Hoog-Labouret, N.; Jimenez, M.; Nowak, F.; Deley, M.-C.L.; Pérol, D.; Cailliot, C.; Raynaud, J.; Vassal, G. Equal access to innovative therapies and precision cancer care. Nat. Rev. Clin. Oncol. 2016, 13, 385-393. [CrossRef] [PubMed]

60. Mo, H.-N.; Liu, P. Targeting MET in cancer therapy. Chronic Dis. Transl. Med. 2017, 3, 148-153. [CrossRef] [PubMed]

61. Pécuchet, N.; Vieira, T.; Rabbe, N.; Antoine, M.; Blons, H.; Cadranel, J.; Laurent-Puig, P.; Wislez, M. Molecular classification of pulmonary sarcomatoid carcinomas suggests new therapeutic opportunities. Ann. Oncol. 2017, 28, 1597-1604. [CrossRef] [PubMed]

62. Maroun, C.R.; Rowlands, T. The Met receptor tyrosine kinase: A key player in oncogenesis and drug resistance. Pharmacol. Ther. 2014, 142, 316-338. [CrossRef] [PubMed]

63. Neal, J.W.; Dahlberg, S.E.; Wakelee, H.A.; Aisner, S.C.; Bowden, M.; Huang, Y.; Carbone, D.P.; Gerstner, G.J.; Lerner, R.E.; Rubin, J.L.; et al. ECOG-ACRIN 1512 Investigators Erlotinib, cabozantinib, or erlotinib plus cabozantinib as second-line or third-line treatment of patients with EGFR wild-type advanced non-small-cell lung cancer (ECOG-ACRIN 1512): A randomised, controlled, open-label, multicentre, phase 2 trial. Lancet Oncol. 2016, 17, 1661-1671. [CrossRef] [PubMed]

64. Spigel, D.R.; Ervin, T.J.; Ramlau, R.A.; Daniel, D.B.; Goldschmidt, J.H.; Blumenschein, G.R.; Krzakowski, M.J.; Robinet, G.; Godbert, B.; Barlesi, F.; et al. Randomized phase II trial of Onartuzumab in combination with erlotinib in patients with advanced non-small-cell lung cancer. J. Clin. Oncol. 2013, 31, 4105-4114. [CrossRef] [PubMed] 
65. Paik, P.K.; Drilon, A.; Fan, P.-D.; Yu, H.; Rekhtman, N.; Ginsberg, M.S.; Borsu, L.; Schultz, N.; Berger, M.F.; Rudin, C.M.; et al. Response to MET inhibitors in patients with stage IV lung adenocarcinomas harboring MET mutations causing exon 14 skipping. Cancer Discov. 2015, 5, 842-849. [CrossRef] [PubMed]

66. Jänne, P.A.; van den Heuvel, M.M.; Barlesi, F.; Cobo, M.; Mazieres, J.; Crinò, L.; Orlov, S.; Blackhall, F.; Wolf, J.; Garrido, P.; et al. Selumetinib Plus Docetaxel Compared With Docetaxel Alone and Progression-Free Survival in Patients With KRAS-Mutant Advanced Non-Small Cell Lung Cancer: The SELECT-1 Randomized Clinical Trial. JAMA 2017, 317, 1844-1853. [CrossRef] [PubMed]

67. Golding, B.; Luu, A.; Jones, R.; Viloria-Petit, A.M. The function and therapeutic targeting of anaplastic lymphoma kinase (ALK) in non-small cell lung cancer (NSCLC). Mol. Cancer 2018, 17, 52. [CrossRef] [PubMed]

68. Solomon, B.J.; Mok, T.; Kim, D.-W.; Wu, Y.-L.; Nakagawa, K.; Mekhail, T.; Felip, E.; Cappuzzo, F.; Paolini, J.; Usari, T.; et al. PROFILE 1014 Investigators First-line crizotinib versus chemotherapy in ALK-positive lung cancer. N. Engl. J. Med. 2014, 371, 2167-2177. [CrossRef] [PubMed]

69. Shaw, A.T.; Kim, T.M.; Crinò, L.; Gridelli, C.; Kiura, K.; Liu, G.; Novello, S.; Bearz, A.; Gautschi, O.; Mok, T.; et al. Ceritinib versus chemotherapy in patients with ALK-rearranged non-small-cell lung cancer previously given chemotherapy and crizotinib (ASCEND-5): A randomised, controlled, open-label, phase 3 trial. Lancet Oncol. 2017, 18, 874-886. [CrossRef]

70. Peters, S.; Camidge, D.R.; Shaw, A.T.; Gadgeel, S.; Ahn, J.S.; Kim, D.-W.; Ou, S.-H.I.; Pérol, M.; Dziadziuszko, R.; Rosell, R.; et al. ALEX Trial Investigators Alectinib versus Crizotinib in Untreated ALK-Positive Non-Small-Cell Lung Cancer. N. Engl. J. Med. 2017, 377, 829-838. [CrossRef] [PubMed]

71. Gainor, J.F.; Dardaei, L.; Yoda, S.; Friboulet, L.; Leshchiner, I.; Katayama, R.; Dagogo-Jack, I.; Gadgeel, S.; Schultz, K.; Singh, M.; et al. Molecular Mechanisms of Resistance to First- and Second-Generation ALK Inhibitors in ALK-Rearranged Lung Cancer. Cancer Discov. 2016, 6, 1118-1133. [CrossRef] [PubMed]

72. Katayama, R.; Friboulet, L.; Koike, S.; Lockerman, E.L.; Khan, T.M.; Gainor, J.F.; Iafrate, A.J.; Takeuchi, K.; Taiji, M.; Okuno, Y.; et al. Two novel ALK mutations mediate acquired resistance to the next-generation ALK inhibitor alectinib. Clin. Cancer Res. 2014, 20, 5686-5696. [CrossRef] [PubMed]

73. Bergethon, K.; Shaw, A.T.; Ou, S.-H.I.; Katayama, R.; Lovly, C.M.; McDonald, N.T.; Massion, P.P.; Siwak-Tapp, C.; Gonzalez, A.; Fang, R.; et al. ROS1 rearrangements define a unique molecular class of lung cancers. J. Clin. Oncol. 2012, 30, 863-870. [CrossRef] [PubMed]

74. Gainor, J.F.; Tseng, D.; Yoda, S.; Dagogo-Jack, I.; Friboulet, L.; Lin, J.J.; Hubbeling, H.G.; Dardaei, L.; Farago, A.F.; Schultz, K.R.; et al. Patterns of Metastatic Spread and Mechanisms of Resistance to Crizotinib in ROS1-Positive Non-Small-Cell Lung Cancer. JCO Precis. Oncol. 2017, 2017. [CrossRef] [PubMed]

75. Wu, Y.-L.; Yang, J.C.-H.; Kim, D.-W.; Lu, S.; Zhou, J.; Seto, T.; Yang, J.-J.; Yamamoto, N.; Ahn, M.-J.; Takahashi, T.; et al. Phase II Study of Crizotinib in East Asian Patients With ROS1-Positive Advanced Non-Small-Cell Lung Cancer. J. Clin. Oncol. 2018, 36, 1405-1411. [CrossRef] [PubMed]

76. Facchinetti, F.; Caramella, C.; Auger, N.; Planchard, D.; Adam, J.; Lacroix, L.; Remon, J.; Massard, C.; Soria, J.-C.; Friboulet, L.; et al. Crizotinib primary resistance overcome by ceritinib in a patient with ALK-rearranged non-small cell lung cancer. Tumori 2016, 102. [CrossRef] [PubMed]

77. Lin, C.; Wang, S.; Xie, W.; Chang, J.; Gan, Y. The RET fusion gene and its correlation with demographic and clinicopathological features of non-small cell lung cancer: A meta-analysis. Cancer Biol. Ther. 2015, 16, 1019-1028. [CrossRef] [PubMed]

78. Nakaoku, T.; Kohno, T.; Araki, M.; Niho, S.; Chauhan, R.; Knowles, P.P.; Tsuchihara, K.; Matsumoto, S.; Shimada, Y.; Mimaki, S.; et al. A secondary RET mutation in the activation loop conferring resistance to vandetanib. Nat. Commun. 2018, 9, 625. [CrossRef] [PubMed]

79. Lin, J.J.; Kennedy, E.; Sequist, L.V.; Brastianos, P.K.; Goodwin, K.E.; Stevens, S.; Wanat, A.C.; Stober, L.L.; Digumarthy, S.R.; Engelman, J.A.; et al. Clinical Activity of Alectinib in Advanced RET-Rearranged Non-Small Cell Lung Cancer. J. Thorac. Oncol. 2016, 11, 2027-2032. [CrossRef] [PubMed]

80. Ferrara, R.; Auger, N.; Auclin, E.; Besse, B. Clinical and Translational Implications of RET Rearrangements in Non-Small Cell Lung Cancer. J. Thorac. Oncol. 2018, 13, 27-45. [CrossRef] [PubMed]

81. Vaishnavi, A.; Capelletti, M.; Le, A.T.; Kako, S.; Butaney, M.; Ercan, D.; Mahale, S.; Davies, K.D.; Aisner, D.L.; Pilling, A.B.; et al. Oncogenic and drug sensitive NTRK1 rearrangements in lung cancer. Nat. Med. 2013, 19, 1469-1472. [CrossRef] [PubMed] 
82. Farago, A.F.; Le, L.P.; Zheng, Z.; Muzikansky, A.; Drilon, A.; Patel, M.; Bauer, T.M.; Liu, S.V.; Ou, S.-H.I.; Jackman, D.; et al. Durable Clinical Response to Entrectinib in NTRK1-Rearranged Non-Small Cell Lung Cancer. J. Thorac. Oncol. 2015, 10, 1670-1674. [CrossRef] [PubMed]

83. Ricciuti, B.; Brambilla, M.; Metro, G.; Baglivo, S.; Matocci, R.; Pirro, M.; Chiari, R. Targeting NTRK fusion in non-small cell lung cancer: Rationale and clinical evidence. Med. Oncol. 2017, 34, 105. [CrossRef] [PubMed]

84. Kohno, T.; Nakaoku, T.; Tsuta, K.; Tsuchihara, K.; Matsumoto, S.; Yoh, K.; Goto, K. Beyond ALK-RET, ROS1 and other oncogene fusions in lung cancer. Transl. Lung Cancer Res. 2015, 4, 156-164. [CrossRef] [PubMed]

85. Gay, N.D.; Wang, Y.; Beadling, C.; Warrick, A.; Neff, T.; Corless, C.L.; Tolba, K. Durable Response to Afatinib in Lung Adenocarcinoma Harboring NRG1 Gene Fusions. J. Thorac. Oncol. 2017, 12, e107-e110. [CrossRef] [PubMed]

86. Drilon, A.; Somwar, R.; Mangatt, B.P.; Edgren, H.; Desmeules, P.; Ruusulehto, A.; Smith, R.S.; Delasos, L.; Vojnic, M.; Plodkowski, A.J.; et al. Response to ERBB3-Directed Targeted Therapy in NRG1-Rearranged Cancers. Cancer Discov. 2018. [CrossRef] [PubMed]

87. Vendrell, J.A.; Taviaux, S.; Béganton, B.; Godreuil, S.; Audran, P.; Grand, D.; Clermont, E.; Serre, I.; Szablewski, V.; Coopman, P.; et al. Detection of known and novel ALK fusion transcripts in lung cancer patients using next-generation sequencing approaches. Sci. Rep. 2017, 7, 12510. [CrossRef] [PubMed]

88. Mertens, F.; Tayebwa, J. Evolving techniques for gene fusion detection in soft tissue tumours. Histopathology 2014, 64, 151-162. [CrossRef] [PubMed]

89. Zhu, Y.-C.; Zhou, Y.-F.; Wang, W.-X.; Xu, C.-W.; Zhuang, W.; Du, K.-Q.; Chen, G. CEP72-ROS1: A novel ROS1 oncogenic fusion variant in lung adenocarcinoma identified by next-generation sequencing. Thorac. Cancer 2018, 9, 652-655. [CrossRef] [PubMed]

90. Velizheva, N.P.; Rechsteiner, M.P.; Valtcheva, N.; Freiberger, S.N.; Wong, C.E.; Vrugt, B.; Zhong, Q.; Wagner, U.; Moch, H.; Hillinger, S.; et al. Targeted next-generation-sequencing for reliable detection of targetable rearrangements in lung adenocarcinoma-a single center retrospective study. Pathol. Res. Pract. 2018, 214, 572-578. [CrossRef] [PubMed]

91. Le Mercier, M.; De Nève, N.; Blanchard, O.; Remmelink, M.; Weynand, B.; Salmon, I.; D’Haene, N. Clinical application of targeted next generation sequencing for lung cancer patients. Belgian J. Med. Oncol. 2015, 27, 2-8.

92. Lih, C.-J.; Sims, D.J.; Harrington, R.D.; Polley, E.C.; Zhao, Y.; Mehaffey, M.G.; Forbes, T.D.; Das, B.; Walsh, W.D.; Datta, V.; et al. Analytical Validation and Application of a Targeted Next-Generation Sequencing Mutation-Detection Assay for Use in Treatment Assignment in the NCI-MPACT Trial. J. Mol. Diagn. JMD 2016, 18, 51-67. [CrossRef] [PubMed]

93. Shao, D.; Lin, Y.; Liu, J.; Wan, L.; Liu, Z.; Cheng, S.; Fei, L.; Deng, R.; Wang, J.; Chen, X.; et al. A targeted next-generation sequencing method for identifying clinically relevant mutation profiles in lung adenocarcinoma. Sci. Rep. 2016, 6, 22338. [CrossRef] [PubMed]

94. Bennett, N.C.; Farah, C.S. Next-generation sequencing in clinical oncology: Next steps towards clinical validation. Cancers 2014, 6, 2296-2312. [CrossRef] [PubMed]

95. Sanchez-Cespedes, M.; Parrella, P.; Esteller, M.; Nomoto, S.; Trink, B.; Engles, J.M.; Westra, W.H.; Herman, J.G.; Sidransky, D. Inactivation of LKB1/STK11 is a common event in adenocarcinomas of the lung. Cancer Res. 2002, 62, 3659-3662. [PubMed]

96. Fang, R.; Zheng, C.; Sun, Y.; Han, X.; Gao, B.; Li, C.; Liu, H.; Wong, K.-K.; Liu, X.-Y.; Chen, H.; et al. Integrative genomic analysis reveals a high frequency of LKB1 genetic alteration in Chinese lung adenocarcinomas. J. Thorac. Oncol. 2014, 9, 254-258. [CrossRef] [PubMed]

97. Zhao, R.-X.; Xu, Z.-X. Targeting the LKB1 tumor suppressor. Curr. Drug Targets 2014, 15, 32-52. [CrossRef] [PubMed]

98. Moghadasi, S.; Eccles, D.M.; Devilee, P.; Vreeswijk, M.P.G.; van Asperen, C.J. Classification and Clinical Management of Variants of Uncertain Significance in High Penetrance Cancer Predisposition Genes. Hum. Mutat. 2016, 37, 331-336. [CrossRef] [PubMed]

99. Kohsaka, S.; Nagano, M.; Ueno, T.; Suehara, Y.; Hayashi, T.; Shimada, N.; Takahashi, K.; Suzuki, K.; Takamochi, K.; Takahashi, F.; et al. A method of high-throughput functional evaluation ofEGFRgene variants of unknown significance in cancer. Sci. Transl. Med. 2017, 9. [CrossRef] [PubMed]

100. Mandel, P.; Metais, P. [Les acides nucleiques du plasma sanguin chez l'homme]. C. R. Seances Soc. Biol. Fil. 1948, 142, 241-243. [PubMed] 
101. Pécuchet, N.; Rozenholc, Y.; Zonta, E.; Pietrasz, D.; Didelot, A.; Combe, P.; Gibault, L.; Bachet, J.-B.; Taly, V.; Fabre, E.; et al. Analysis of Base-Position Error Rate of Next-Generation Sequencing to Detect Tumor Mutations in Circulating DNA. Clin. Chem. 2016, 62, 1492-1503. [CrossRef] [PubMed]

102. Castellanos-Rizaldos, E.; Grimm, D.G.; Tadigotla, V.; Hurley, J.; Healy, J.; Neal, P.L.; Sher, M.; Venkatesan, R.; Karlovich, C.; Raponi, M.; et al. Exosome-based Detection of EGFR T790M in Plasma from Non-Small Cell Lung Cancer Patients. Clin. Cancer Res. 2018. [CrossRef] [PubMed]

103. Cui, S.; Cheng, Z.; Qin, W.; Jiang, L. Exosomes as a liquid biopsy for lung cancer. Lung Cancer 2018, 116, 46-54. [CrossRef] [PubMed]

104. Couraud, S.; Vaca-Paniagua, F.; Villar, S.; Oliver, J.; Schuster, T.; Blanché, H.; Girard, N.; Trédaniel, J.; Guilleminault, L.; Gervais, R.; et al. BioCAST/IFCT-1002 investigators Noninvasive diagnosis of actionable mutations by deep sequencing of circulating free DNA in lung cancer from never-smokers: A proof-of-concept study from BioCAST/IFCT-1002. Clin. Cancer Res. 2014, 20, 4613-4624. [CrossRef] [PubMed]

105. Normanno, N.; Denis, M.G.; Thress, K.S.; Ratcliffe, M.; Reck, M. Guide to detecting epidermal growth factor receptor (EGFR) mutations in ctDNA of patients with advanced non-small-cell lung cancer. Oncotarget 2017, 8, 12501-12516. [CrossRef] [PubMed]

106. Uchida, J.; Kato, K.; Kukita, Y.; Kumagai, T.; Nishino, K.; Daga, H.; Nagatomo, I.; Inoue, T.; Kimura, M.; Oba, S.; et al. Diagnostic Accuracy of Noninvasive Genotyping of EGFR in Lung Cancer Patients by Deep Sequencing of Plasma Cell-Free DNA. Clin. Chem. 2015, 61, 1191-1196. [CrossRef] [PubMed]

107. Plagnol, V.; Woodhouse, S.; Howarth, K.; Lensing, S.; Smith, M.; Epstein, M.; Madi, M.; Smalley, S.; Leroy, C.; Hinton, J.; et al. Analytical validation of a next generation sequencing liquid biopsy assay for high sensitivity broad molecular profiling. PLoS ONE 2018, 13, e0193802. [CrossRef] [PubMed]

108. Mambetsariev, I.; Vora, L.; Yu, K.W.; Salgia, R. Effective osimertinib treatment in a patient with discordant T790 M mutation detection between liquid biopsy and tissue biopsy. BMC Cancer 2018, 18, 314. [CrossRef] [PubMed]

109. McCoach, C.E.; Blakely, C.M.; Banks, K.C.; Levy, B.; Chue, B.M.; Raymond, V.M.; Le, A.T.; Lee, C.E.; Diaz, J.; Waqar, S.N.; et al. Clinical Utility of Cell-Free DNA for the Detection of ALK Fusions and Genomic Mechanisms of ALK Inhibitor Resistance in Non-Small Cell Lung Cancer. Clin. Cancer Res. 2018. [CrossRef] [PubMed]

110. Provencio, M.; Torrente, M.; Calvo, V.; Pérez-Callejo, D.; Gutiérrez, L.; Franco, F.; Pérez-Barrios, C.; Barquín, M.; Royuela, A.; García-García, F.; et al. Prognostic value of quantitative ctDNA levels in non small cell lung cancer patients. Oncotarget 2018, 9, 488-494. [CrossRef] [PubMed]

111. Hyun, M.H.; Sung, J.S.; Kang, E.J.; Choi, Y.J.; Park, K.H.; Shin, S.W.; Lee, S.Y.; Kim, Y.H. Quantification of circulating cell-free DNA to predict patient survival in non-small-cell lung cancer. Oncotarget 2017, 8, 94417-94430. [CrossRef] [PubMed]

112. Pécuchet, N.; Zonta, E.; Didelot, A.; Combe, P.; Thibault, C.; Gibault, L.; Lours, C.; Rozenholc, Y.; Taly, V.; Laurent-Puig, P.; et al. Base-Position Error Rate Analysis of Next-Generation Sequencing Applied to Circulating Tumor DNA in Non-Small Cell Lung Cancer: A Prospective Study. PLoS Med. 2016, 13, e1002199. [CrossRef] [PubMed]

113. Van Allen, E.M.; Miao, D.; Schilling, B.; Shukla, S.A.; Blank, C.; Zimmer, L.; Sucker, A.; Hillen, U.; Foppen, M.H.G.; Goldinger, S.M.; et al. Genomic correlates of response to CTLA-4 blockade in metastatic melanoma. Science 2015, 350, 207-211. [CrossRef] [PubMed]

114. Brahmer, J.; Reckamp, K.L.; Baas, P.; Crinò, L.; Eberhardt, W.E.E.; Poddubskaya, E.; Antonia, S.; Pluzanski, A.; Vokes, E.E.; Holgado, E.; et al. Nivolumab versus Docetaxel in Advanced Squamous-Cell Non-Small-Cell Lung Cancer. N. Engl. J. Med. 2015, 373, 123-135. [CrossRef] [PubMed]

115. Yoneshima, Y.; Ijichi, K.; Anai, S.; Ota, K.; Otsubo, K.; Iwama, E.; Tanaka, K.; Oda, Y.; Nakanishi, Y.; Okamoto, I. PD-L1 expression in lung adenocarcinoma harboring EGFR mutations or ALK rearrangements. Lung Cancer 2018, 118, 36-40. [CrossRef] [PubMed]

116. Ota, K.; Azuma, K.; Kawahara, A.; Hattori, S.; Iwama, E.; Tanizaki, J.; Harada, T.; Matsumoto, K.; Takayama, K.; Takamori, S.; et al. Induction of PD-L1 Expression by the EML4-ALK Oncoprotein and Downstream Signaling Pathways in Non-Small Cell Lung Cancer. Clin. Cancer Res. 2015, 21, 4014-4021. [CrossRef] [PubMed] 
117. Hanna, N.; Johnson, D.; Temin, S.; Baker, S.; Brahmer, J.; Ellis, P.M.; Giaccone, G.; Hesketh, P.J.; Jaiyesimi, I.; Leighl, N.B.; et al. Systemic Therapy for Stage IV Non-Small-Cell Lung Cancer: American Society of Clinical Oncology Clinical Practice Guideline Update. J. Clin. Oncol. 2017, 35, 3484-3515. [CrossRef] [PubMed]

118. Haratani, K.; Hayashi, H.; Tanaka, T.; Kaneda, H.; Togashi, Y.; Sakai, K.; Hayashi, K.; Tomida, S.; Chiba, Y.; Yonesaka, K.; et al. Tumor immune microenvironment and nivolumab efficacy in EGFR mutation-positive non-small-cell lung cancer based on T790M status after disease progression during EGFR-TKI treatment. Ann. Oncol. 2017, 28, 1532-1539. [CrossRef] [PubMed]

119. Lee, C.K.; Man, J.; Lord, S.; Links, M.; Gebski, V.; Mok, T.; Yang, J.C.-H. Checkpoint Inhibitors in Metastatic EGFR-Mutated Non-Small Cell Lung Cancer-A Meta-Analysis. J. Thorac. Oncol. 2017, 12, 403-407. [CrossRef] [PubMed]

120. Dong, Z.-Y.; Zhong, W.-Z.; Zhang, X.-C.; Su, J.; Xie, Z.; Liu, S.-Y.; Tu, H.-Y.; Chen, H.-J.; Sun, Y.-L.; Zhou, Q.; et al. Potential Predictive Value of TP53 and KRAS Mutation Status for Response to PD-1 Blockade Immunotherapy in Lung Adenocarcinoma. Clin. Cancer Res. 2017, 23, 3012-3024. [CrossRef] [PubMed]

121. Skoulidis, F.; Hellmann, M.D.; Awad, M.M.; Rizvi, H.; Carter, B.W.; Denning, W.; Elamin, Y.; Zhang, J.; Leonardi, G.C.; Halpenny, D.; et al. STK11/LKB1 co-mutations to predict for de novo resistance to PD-1/PD-L1 axis blockade in KRAS-mutant lung adenocarcinoma. J. Clin. Oncol. 2017, 35, 9016-9016. [CrossRef]

122. Koyama, S.; Akbay, E.A.; Li, Y.Y.; Aref, A.R.; Skoulidis, F.; Herter-Sprie, G.S.; Buczkowski, K.A.; Liu, Y.; Awad, M.M.; Denning, W.L.; et al. STK11/LKB1 Deficiency Promotes Neutrophil Recruitment and Proinflammatory Cytokine Production to Suppress T-cell Activity in the Lung Tumor Microenvironment. Cancer Res. 2016, 76, 999-1008. [CrossRef] [PubMed]

123. Mansuet-Lupo, A.; Alifano, M.; Pécuchet, N.; Biton, J.; Becht, E.; Goc, J.; Germain, C.; Ouakrim, H.; Régnard, J.-F.; Cremer, I.; et al. Intratumoral Immune Cell Densities Are Associated with Lung Adenocarcinoma Gene Alterations. Am. J. Respir. Crit. Care Med. 2016, 194, 1403-1412. [CrossRef] [PubMed]

124. Rizvi, N.A.; Hellmann, M.D.; Snyder, A.; Kvistborg, P.; Makarov, V.; Havel, J.J.; Lee, W.; Yuan, J.; Wong, P.; Ho, T.S.; et al. Cancer immunology. Mutational landscape determines sensitivity to PD-1 blockade in non-small cell lung cancer. Science 2015, 348, 124-128. [CrossRef] [PubMed]

125. Brown, S.D.; Warren, R.L.; Gibb, E.A.; Martin, S.D.; Spinelli, J.J.; Nelson, B.H.; Holt, R.A. Neo-antigens predicted by tumor genome meta-analysis correlate with increased patient survival. Genome Res. 2014, 24, 743-750. [CrossRef] [PubMed]

126. Rizvi, H.; Sanchez-Vega, F.; La, K.; Chatila, W.; Jonsson, P.; Halpenny, D.; Plodkowski, A.; Long, N.; Sauter, J.L.; Rekhtman, N.; et al. Molecular Determinants of Response to Anti-Programmed Cell Death (PD)-1 and Anti-Programmed Death-Ligand 1 (PD-L1) Blockade in Patients with Non-Small-Cell Lung Cancer Profiled with Targeted Next-Generation Sequencing. J. Clin. Oncol. 2018, 36, 633-641. [CrossRef] [PubMed]

127. Steuer, C.E.; Ramalingam, S.S. Tumor Mutation Burden: Leading Immunotherapy to the Era of Precision Medicine? J. Clin. Oncol. 2018, 36, 631-632. [CrossRef] [PubMed]

(C) 2018 by the authors. Licensee MDPI, Basel, Switzerland. This article is an open access article distributed under the terms and conditions of the Creative Commons Attribution (CC BY) license (http://creativecommons.org/licenses/by/4.0/). 